\title{
Die konstellasie taalbegrip-logika in die Middeleeuse filosofie (1): Augustinus tot Aquinas
}

\author{
Author: \\ Johann Beukes ${ }^{1}$ \\ Affiliation: \\ ${ }^{1}$ Department of Philosophy, \\ University of Johannesburg, \\ South Africa

\section{Correspondence to:} \\ Johann Beukes \\ Email: \\ jbeukes@vodamail.co.za \\ Postal address: \\ PO Box 784849, Sandton \\ 2146, South Africa

\section{Dates:} \\ Received: 04 May 2011 \\ Accepted: 25 July 2011 \\ Published: 04 Nov. 2011 \\ How to cite this article: \\ Beukes, J., 2011, 'Die \\ konstellasie taalbegrip-logika \\ in die Middeleeuse filosofie \\ (1): Augustinus tot Aquinas', \\ HTS Teologiese Studies/ \\ Theological Studies 67(3), \\ Art. \#1072, 15 pages. http:// \\ dx.doi.org/10.4102/hts. \\ v67i3.1072
}

(C) 2011. The Authors. Licensee: AOSIS OpenJournals. This work is licensed under the Creative Commons Attribution License.
The constellation language-logic in medieval philosophy (1): St Augustine to St Aquinas

This series of two articles provides an in-depth overview of some of the most prominent (and some of the most underpublished) medieval thinkers' stance on the constellation of language and logic, thus as a combined and condensed problem in Western philosophy between the 5th and 15th centuries. The articles form part of a rehabilitating series of modern-critical articles on understated and marginalised themes, texts and figures in medieval philosophy. The positions of the well-known philosophers that are covered in the two articles, St Augustine, Peter Abelard, St Thomas Aquinas, John Duns Scotus and William of Ockham, are juxtaposed with some less familiar philosophical positions, amongst others those of Boethius, Peter of Spain, John Wyclif and Peter de Rivo.

\section{Augustinus: Verbum, dictio, dicibile, res}

Hierdie reeks van twee artikels poog om 'n intensiewe oorsig van die mees prominente (en daarteenoor sommige van die mees ondergepubliseerde) Middeleeuse denkers se posisies te verskaf ten aansien van die konstellasie van taalbegrip en logika, dus as 'n samehangende probleem in die Westerse filosofie tussen die 5 de en 15de eeu. Die perspektiewe van bekende ${ }^{1}$ Middeleeuse filosowe soos Augustinus, Petrus Abelardus, Thomas Aquinas, Johannes Duns Skotus en Willem van Ockham, sal jukstaponeer ${ }^{2}$ word met die minder bekende en tradisioneel ondergepubliseerde perspektiewe van onder meer Boethius, Petrus Hispanus, Johannes Wyclif en Petrus de Rivo.

Indien die denkarbeid van Augustinus as die vroegste ${ }^{3}$ geleier van die diverse filosofiese denksisteme van die Middeleeue kan dien en indien dit waar is dat een van Augustinus se mees

1.Daar bestaan ' $n$ modernistiese vooroordeel teenoor die Middeleeue en volgehoue aanklagte van intellektuele skaarste, skolastiese rigiditeit en religieuse fiksasie in die 'Donker Tyd' (vgl. Copleston 1972:6), ' $n$ knaende vooroordeel waaraan selfs die sogenaamde 'postmoderne' nie kon ontkom nie (Beukes 2005:1102). Die vraag volg of daar wel nog vandag iets soos ' $n$ 'bekende Middeleeuse filosoof' buite die konteks van Middeleeuse nisnavorsing is (vir die modernkritiese stemming van die projek waarvan hierdie artike deel vorm, kyk voetnota 4). Met 'bekend' word hier daarom weliswaar 'bemind' bedoel: daardie filosowe wat wel ensiklopedies behoorlik geboekstaaf is en in enige inleidingswerk tot die Middeleeuse filosofie aangetref sal word. Dit sou ten minste insluit Augustinus, Lombardus, Abelardus, Anselmus, Aquinas, Johannes Duns Skotus en Willem van Ockham. Wanneer ' $n$ inleidingswerk we sistematies aandag gee aan figure soos Boethius, Alkuin, Johannes Skotus Eriugena (JohSE), Hendrik van Gent, Sigerius van Brabant, Nikolaus van Kusa, Meester Eckhardt, of aan die Arabiese denkers, ook buite-om Avicenna en Averroes, of aan die Joodse denkers, ook buite-om Moses Maimonides, of die werklik ondergepubliseerde Westerse denkers waarvan sommige in hierdie artikel aan die woord gebring word, onder meer Petrus Hispanus en Petrus de Rivo, is dit onkonvensioneel en vir die navorsing ' $n$ aanwins. So ' $n$

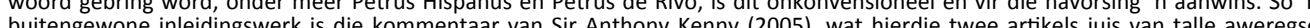
buitengewone inleidingswerk is die kommentaar van Sir Anthony Kenny (2005), wat hierdie twee artikels juis van talle aweregse van bekend en onbekend, dus ook mee tot 'n verbreding van die gestandaardiseerde (inderdaad moderne) ensiklopedie van die viddeleeuse filosofie.

2.Resepsie geskied sover moontlik vanuit die primêre tekste aan die hand van die seleksies en tekstuele geleiers van Bosley en Tweedale (2004), Copleston (1972), Kenny (2005), Luscombe (2004) en Marenbon (2007), hoewel betroubare Engelse en Duitse vertalings vanuit die Latyn gebruik is, waar nodig, vir semantiese kontroledoeleindes.

3.Augustinus (354 n.C. -430 n.C.) se posisie in die Middeleeuse ensiklopedie sal waarskynlik altyd in dispuut wees, synde die eerste Middeleeuse denker (indien die eerste barbaarse inval in Rome in 410 n.C. na die outeur se filosofies-historiese argument elders as die aanvang van die Middeleeue aanvaar word [Beukes 2011:1]), of die laaste denker van die Neoplatoniese of Patristiese periode, of selfs die laaste antieke denker, of dalk wel die wesenlike deurgangsfilosoof tussen die antieke en die Middeleeue (vgl. Luscombe 2004:9). Die gevierde Middeleeuse navorser Fredrick Copleston [S.J.] (1972:17) plaas Augustinus baie duidelik in die Patristiese periode terwyl Kenny (2005:3-5) Augustinus om tematiese oorwegings as 'n pertinent Middeleeuse denker wil hanteer. Die gerespekteerde frontnavorsers David Luscombe (2004:9) en John Marenbon (2007:15) volstaan met die skarnieraanduiding. Augustinus is in hierdie frontnavorsers kwaliteit eietydse navorsingsgeselskap die denker wat die periodiseringsvraag in die Middeleeuse filosofie telkens weer oproep. Hoewel 'n gestandaardiseerde periodisering van Middeleeuse filosofie altyd oop vir hersiening behoort te wees, kan daar duidelik aanwysbaar met ses institusiehistoriese periodes in hierdie millenniumlange epog gewerk word. Die outeur se elders beredeneerde voorstel vir so ' $\mathrm{n}$ historiese skema, wat ' $\mathrm{n}$ wesenlike saak in die groter $\mathrm{m}$ :
filosofie is, sien as volg daaruit (vgl. breedvoeriger Beukes 2011:2ev):

1. die vroeë of post-Romeinse periode (5de-7de eeu [410 \{Alaricus I; eerste barbaarse inval in Rome\} tot 663 \{Konstantyn II\}], met Augustinus [354-430] en Boethius [480-524] as die belangrikste filosofiese eksponente)

2. die Carolingiese periode (8ste-9de eeu [742 \{Dood Karel I\} tot 840 \{Dood Lodewyk 1\}], met Alkuin van York [730-804] en Johannes Skotus Eriugena [815-877] as die belangrikste filosofiese geleiers van die Carolingiese Renaissance)

3. die post-Carolingiese periode (10de-12de eeu [ 877 \{Dood JohSE\} tot 1095 \{aanvang van die kruistogte\}, met Anselmus [10331109] en Abelardus [1079-1142] as die mees gevolgryke onder die filosowe wat sou baat by die sporadiese rehabilitering van die antieke in die Carolingiese Renaissance)

4. die vroeë universiteitsperiode (12de-13de eeu [1088 \{stigting van die Universiteit van Bologne, die eerste Europese universiteit\} tot 1225 \{Geboorte Thomas Aquinas\}, en die opkoms van die 12e-eeuse filosofiese skole])

5. die skolastiese periode (13de-14de eeu [1274 \{Dood Aquinas\} tot 1348 \{Dood Willem van Ockham\}, met Thomas Aquinas, Hendrik van Gent, Johannes Duns Skotus, en Willem van Ockham as die beroemdstes onder die hoë skolastici])

6. die laat-skolastiese periode (15de-16de eeu [Geboorte 1401 Nikolaus van Kusa, die laaste Middeleeuse of eerste 'moderne' filosoof\} tot 1517 \{Martin Luther en die aanvang van die Wes-Europese Kerkhervorming\}], vgl. Beukes 2011:2)

Die outeur kies dus, met inbegrip van die statuur van Copleston in die navorsing, om Augustinus saam met Kenny, Luscombe en Marenbon binne die Middeleeuse korpus te plaas, op sterkte van die datering van die vroeë of post-Romeinse periode hierbo. 
dwingende interesses taalbegrip was, om daarvanuit logiese postulate oor God en die werklikheid te kon presenteer (vgl. Colish 1968:3; Weinberg 1964:11), is die voorhande vraag hoe hierdie eerste sistematiese denker van die Middeleeue se perspektief op die verhouding tussen taalbegrip en logika daar uitsien. Hierdie verhouding tussen taalbegrip en logika stel in diverse Middeleeuse denksisteme 'n konstellasie van filosofiese belange daar wat eietyds ${ }^{4}$ herondersoek kan word. Ludwig Wittgenstein (1889-1951) het in die beroemde openingspassasie van sy Philosophical Investigations (1953:2) Augustinus se taalfilosofiese vertrekpunt as teiken van sy eie taalfilosofiese kritiek opgestel (vgl. Kenny 2005:115-118). Die passasie wat so polemies dog premissegewys deur Wittgenstein gesiteer is, kom uit Augustinus (1992) se beroemde Confessiones:

Wanneer my ouers die een of ander objek by ' $n$ naam genoem het en na die betrokke objek beweeg het, het ek besef dat die objek benoem is deur die klank wat my ouers geuiter het wanneer hulle die oogmerk gehad het om na die objek te verwys ... Ek het geleer dat woorde herhaaldelik gebruik word, op 'n spesifieke wyse hoewel in 'n verskeidenheid van stellinge, om na 'n spesifieke objek te verwys ... Ek moes my mond leer om hierdie verwysers te vorm, sodat ek dit kon gebruik om my eie begeertes tot uitdrukking te bring.

(Augustinus 1992:I.8.13)

Volgens Wittgenstein (1953:3ev) verteenwoordig hierdie opvatting, naamlik dat benaming die basis van taalbegrip is en dat die betekenis van 'n woord voltrek in die objek van verwysing, die fundamentele taalfilosofiese probleem van suiwer referensialisme ${ }^{5}$. Augustinus beklemtoon 4.Soos by die Middeleeuse voorgangers, word die debat hier baie implisiet en by voorkeur in voetnotas gevoer. Hierdie reeks van twee artikels is die volgende in 'n reeks oor onderbeklemtoonde tekste, temas en denkers in die Middeleeuse filosofie, gebed in 'n navorsingsprojek wat vanuit die 'Donker Era' as ' $n$ verset teen die verligtende pretensie van die moderne gelees kan word. Die vorige artikel he gefokus op'n gemarginaliseerde teks, Theologia Scholarium, in Abelardus se oeuvre (Beukes 2011). Met die projek as sulks word momentum verleen aan die outeur se selfopgelegde taakstelling om die 'blywende erns van die monnik' in die eietydse filosofie te rehabiliteer en om 'monnikearbeid' rakende waarheid, skoonheid en geregtigheid in die filosofie 'terug te bring' (Beukes 2005:1101-1103,1124-1128). geregtigheid in lis tos liter Hier word implisiet aansluiting gevind by ' $\mathrm{n}$ genuanseerde, sydelingse, dog geldige variant van die sogenaamde postmoderne projek se rehabilitasie van vergete en verlore momente in die geskiedenis, met die oog op die voortgaande verwikkelin van ' $n$ risoom van Westerse herinnering, veral via die werke van Adorno, Heidegge en Foucault - en hier in 'n diskursiewe jukstaposisie ook al die sonderlinge monnike van die Middeleeuse periode, vanaf Augustinus tot by Nikolaus. Die projek fokus om hierdie rede op ' $n$ kreatiewe herlesing van onderbeklemtoonde primêre tekste en ondergekommentarieerde temas en denkers, sowel as netelige metodologiese kwessies, in die Middeleeuse filosofie. Dit gaan eerder oor 'n blootlegging van 'n dialektiek van die Verligting, as wat dit bloot erudisie ten opsigte van die Middeleeue wil reflekteer of verbreed, hoewel erudisie in die Middeleeuse navorsing natuurlik ' $n$ voorwaarde vir betekenisvolle nisuitsette in die betrokke veld is. Dit gaan ten diepste oor die werklikheid dat filosofiese moderniteit gefaal het en ons minder ander opsies laat as om 'voor die moderne' (eerder as in die nou duidelik harlekynagtige 'postmoderne') na die belangrikste vrae te gaan soek: nie na hoofstroom (post)moderne antwoorde nie mar na Middeloeuse vrae. Dit nie na hoofstroom (post)moderne antwoorde nie, maar na Middeleeuse vrae. Dit sal Middeleeuse vrae wees wat filosofiese integriteit in die Westerse register van herinnering sal red, nie die moderne oplossings, vanaf Rousseau tot by Hegel, in die transendentalisering van die subjek, of die epistemologiese eksesse van 'n 'serebraal-koudbloedige, inderdaad "postmoderne" Baudrillard', wat nie 'mee bloed kan ruik' (Beukes 2005:1102) nie. Hierdie projek werk tot so 'n kritieserehabiliterende hervraging vanuit die Middeleeue mee en is in hierdie sin sowe on-modern as on-postmodern, as't ware post-postmodern. Die projek beloof geen teleologiese uitkoms nie, maar' $n$ diskursiewe stilstand, ' $n$ ruimte waar weer gedin kan word oor minstens sommige van die oorwegings wat die Westerse filosofie eens die beste uit die menslike fakulteite laat manifesteer het, totdat hierdie fakulteite deur die narcistiese moderne en karnivalistiese postmoderne oorspan en uiteindelik tot by die rand van ' $n$ onbemiddelde verstaan van waarheid, skoonheid en geregtigheid gebring is (kyk Beukes 2005:1109). Dalk sou dit alles bondig in die een sin gestel kan word: Wanneer vergete en verwaarloosde momente in die Middeleeuse filosofie eietyds lewendig gehou word, dui dit per definisie op 'n modernkritiese trajek.

5. Wittgenstein se resepsie maak dit duidelik dat hy in Augustiniaanse taalfilosofie 'n suiwer referensialisme aan die werk sien, wat na sy lesing die voorloper is van Cartesiaanse epistemologie en Husserl se semantiese fenomenologie: 'Hierdie Cartesiaanse epistemologie en Husserl se semantiese fenomenologie: 'Hierdie
woorde (die aanhaling uit Confessiones, JB) skets 'n duidelike portret van menslike woorde (die aanhaling uit Confessiones, JB) skets 'n duidelike portret van mens
taal. Dit is: die individuele woorde vir taalbenaamde objekte het 'n duidelike volgens Wittgenstein (1953:2) in die gesiteerde passasie bloot die aanleer van die korrekte woord of verwyser vir die beoogde objek of verwysde en maak geen onderskeid tussen verskillende soorte taalbegrippe nie. In die paragraaf direk voorafgaande tot Wittgenstein se gesiteerde paragraaf (Augustinus 1992:I.8.13; Copleston 1972:41; vgl. Kirwan 1991:30), verduidelik Augustinus sy tese egter in meer tegniese, verhelderende terme: die opstel van taalkundige konvensies vooronderstel'n gemeensaamheid of uniformiteit tussen mense in hulle natuurlike, voorkonvensionele reaksies met betrekking tot byvoorbeeld handgebare, 'die natuurlike taal van alle mense' (Augustinus 1992:I.8.13). Die taalkundig-ostensiewe definisie van 'n 'woord' aan die hand van voorbeelde sal 'n kind nie die betekenis van die 'woord' leer nie: 'n Kind moet 'die woord herhaaldelik hoor soos dit korrek in behoorlike sinskonstruksies gebruik (word)' (Augustinus 1992:I.8.13). Die leerproses word begin deur die kind se eie pogings om die kind se eie waarnemings, sensasies en behoeftes voor-taalkundig tot uitdrukking te bring: Dit is egter juis wanneer die kind geleer het hoe om nie te 'wys' nie, maar (verwysend) te praat, dat die leerproses momentum kry. Augustinus (1992:I.8.13) maak hier 'n stelling wat kenmerkend deur Wittgenstein (bv. 1953:244) self beklemtoon is, naamlik dat 'woorde gekonnekteer is met die primitiewe, die natuurlike, die uitdrukking van sensasie'. Dit is dus vreemd dat Augustinus se taalbegrip as voormoderne karikatuur deur Wittgenstein opgestel word: 'n versigtiger lees van Augustinus se teks bring hom trouens nader, eerder as verder, aan Wittgenstein.

Wittgenstein se 'misplaasde skermutseling met Augustinus' (Copleston 1972:42) is 'n goeie voorbeeld van waarom moeite gedoen moet word om Augustinus en al sy Middeleeuse opvolgers rehabiliterend te lees (vgl. Murray 1967:15). Kenny (2005:116), in 'n doelgerigte herinterpretasie, verwys juis na 'n betreklik onderbeklemtoonde teks, De Magistro, gedateer as vroeg (389 n.C.) vanuit die oeuvre en betreklik ondergekommentarieerd in die resepsiegeskiedenis, waarin Augustinus (1978) bogenoemde standpunt breedvoeriger verduidelik. Die tema van hierdie werk, wat wesenlik 'n dialoog tussen Augustinus en sy seun Adeodatus bestryk, gaan (anders as wat die titel pretendeer) nie oor algemene opvoeding nie, maar feitlik sonder uitsondering oor die onderrig en aanleer van woorde. Die werk begin (Augustinus 1978:129-140) met 'n oorsig van die gebruik van taal; ons gebruik taal nie net vir kommunikasie en informasie nie, maar ook om 'God te loof en in die bad te sing' (Augustinus 1978:130; vgl. Kenny 2005:116). Ons kan taal sonder klank gebruik wanneer ons woorde bedink of kognitief vorm: dan gebruik ons taal as wyse waarop herinnering in werking gestel word en objekte van herinnering herroep word. Allermins is Augustinus in terme van ' $n$ suiwer

\footnotetext{
(Voetnota 5 vervolg...)
}

betekenis (Bedeutung [oorspronklike teks, JB]). Die betekenis korreleer met hierdie woord. Dit is die objek waarvoor die woord staan' (Wittgenstein 1953:2). Maar hierdie lesing, soos opvolgend in die hoofteks hierbo aangedui, strook nie met Augustinus se veel meer genuanseerde posisie nie, veral teen die agtergrond van Wittgenstein se opvolgende stelling: 'Augustinus praat nie van enige verskil tussen Wittgenstein se opvolgende stelling: Augustinus praat nie van enige verskil tussen soorte woorde nie. Indien 'n mens taalonderrig op hierdie wyse beskryf, dink jy
hoofsaaklik aan selfstandige naamwoorde soos "tafel", "stoel", "brood" en mense se name, en slegs dan daarna aan die name van sekere handelinge en eienskappe, se name, en slegs dan daarna aan die name van sekere handelinge en eienskappe, 1953:2). 
referensialisme gepreokkupeerd met die verstaan van woorde as blote verwysers: 'Die beweging vanaf verwyser na die werklikheid is nie vanselfsprekend nie' (Augustinus 1978:141; kyk Kirwan 1991:32).

Ostensiewe onderrig, of taalonderrig aan die hand van voorbeelde, se skopus is volgens Augustinus beperk: 'n mens sou byvoorbeeld na 'n 'boom' kon wys, deur daarna met 'n vinger te wys. Alle stoflike objekte en kleure kan so (uit)gewys word. Maar Augustinus (1978:146) wys op twee logiese probleme in ostensiewe verband: woorde soos lidwoorde of bywoorde kan nie 'gewys' word nie, en nog meer fundamenteel, die gebaar van 'wys', net soos die klank van ' $n$ woord, is net 'n teken, 'n verwyser, en nie 'n verwysde werklikheid of verwysing nie. Werkwoorde word op die oog af effektief deur ostensiewe verduideliking ondervang: 'Loop', 'eet' en 'staan' kan dadelik verduidelik word deur te loop, eet of staan. Maar dan vra Augustinus (1978:150) vir Adeodatus: Veronderstel ek is reeds aan die loop wanneer iemand my vra wat 'loop' beteken? Adeodatus antwoord dan dat 'n mens dalk net vinniger moet loop. Maar dadelik, selfs dan met werkwoorde, word die onontkombare dubbelslagtige aard van ostensiewe definisies geopenbaar: As ek vinniger loop, hoe weet ek dat die ostensiewe verduideliking na 'loop' en nie reeds 'draf' nie, verwys? Augustinus konkludeer dan logieserwys dat indien selfs ostensiewe onderrig in terme van koherente betekenis faal, die betekenis van ' $n$ woord nie iets is wat deur 'n menslike leermeester onderrig kan word nie, maar slegs deur 'n leermeester 'binne ons' waarvan die 'huis in die hemel' is (Augustinus 1978:155). So word Augustinus se verduideliking 'n Christelike weergawe van die aanleer van taal binne die ouer konteks van Plato se bekende tesis in Meno dat alle (taal)opvoeding ' $n$ vorm van herinnering is (vgl. Kenny 2005:117; Kirwan 1991:36).

Op hierdie punt begin Augustinus sy taalfilosofie op logiese gronde behoorlik beslag gee. ${ }^{6}$ Eerstens begin Augustinus tekens of verwysers in 'n rudimentêre semiotiek klassifiseer. Alle woorde is tekens, maar nie alle tekens is woorde nie. Daar moet byvoorbeeld onderskei word tussen letters en gebare. Alle name is woorde, maar nie alle woorde is name nie: afgesien van lidwoorde en bywoorde is daar voornaamwoorde en werkwoorde, woorde wat dus tussen ander woorde, binne 'n sinskonstruksie, gebruik moet word (Augustinus 1978:149). Augustinus beklemtoon so die verskil tussen die teken of verwyser en die betekende of verwysde: niemand behoort ' $n$ boom te verwar met die woord vir 'n boom nie, maar sommige woorde, soos lidwoorde of voornaamwoorde, is duidelik woorde-vir-woorde en juis hierin vestig die gevaar van 'n verwarring tussen verwyser en verwysde.

Tweedens beredeneer Augustinus (1978:152ev) die logiese feit dat hoewel nie alle woorde name is nie, dit tog so beskou kan word elke woord ' $n$ naam is in die sin dat elke woord sigself benaam. Selfs ' $n$ 'werkwoord' is in hierdie opsig 'n

6.Vergelyk in die sekondêre literatuur in besonder Bosley en Tweedale (2004:453-454); Copleston (1972:41-42); Kenny (2005:115-118); Luscombe (2004:9-15) en Marenbon (2007:1001-1088, 1988:12ev.). naam, die naam 'werkwoord'. ' Derdens, in De Dialectica (Augustinus 1985:v), ontwikkel Augustinus 'n viervoudige onderskeid van verwysers en verwysdes. Verbum verwys na ' $n$ woord wat geuiter word ter wille van die woord self en verwys na niks buite die woord nie. Wesenlik beteken dit dat die woord 'genoem' word. Dictio verwys na 'n woord wat geuiter word ter wille van iets anders as die woord en verwys na iets buite die woord. Wesenlik beteken dit dat die woord 'gebruik' word. Dicibile verwys na dit wat verstaan word op grond van die uitering van die woord. Wesenlik beteken dit dat die woord 'begryp' word. Res verwys na die woord se verwysde. Wesenlik beteken dit dat die woord ('n saak) 'verwys' of 'beteken'. Augustinus (1985:il-x31) konkludeer in De Dialectica wat hy reeds in Confessiones en De Magistro, soos hierbo uitgewys, geponeer het: (taal)onderrig kan nie sonder tekens of verwysers plaasvind nie, maar dit impliseer nie referensialisme nie.

Vierdens poog Augustinus, weer in De Magistro (Augustinus 1978:161ev; vgl. Kirwan 1991:40), om hierdie epistemologiese noodsaaklikheid van taal met sy 'teorie van verheldering' te ondervang. Om te verstaan wat iemand uiter, moet ons by voorbaat reeds verstaan wat die geuiterde woord beteken. Om hierdie geuiterde waarheid te begryp, moet ons die verwyser of teken dus verstaan vanuit ' $n$ ander oord as die geuiterde woord self. In terme van Augustinus se grootliks Platoniese opvattinge beteken dit dat ' $\mathrm{n}$ metafisiese oorsprong van kennis veronderstel word. Vanuit hierdie Platoniese ideaal argumenteer Augustinus (1978:165ev) dat die enigste wyse waarop waarheid en kennis haalbaar of verstaanbaar word, sou wees wanneer dit in ons deur God geproduseer word. God bring ons tot ' $n$ verheldering van dit wat geuiter word. God is vir Augustinus daarom logieserwys die eerste en laaste grond vir taalfilosofie (Wills 1999:68; Crosson 1999:34).

Hoewel Augustinus nie self ' $n$ formele bydrae tot logika, as 'n progressiewe filosofiese deeldissipline regdeur die Middeleeue, gemaak het nie, is die feit dat sy taalfilosofie duidelik op logiese argumentvoering terugval, betekenisvol. Augustinus trek naamlik die buitelyne van die konstellasie taalbegrip-logika as ' $n$ samehangende probleemstelling in die filosofie. Hierdie probleemstelling sou deur die eerste betekenisvolle Middeleeuse filosoof na Augustinus, naamlik Boethius, opgevolg word.

\section{Boethius: Praedicabiles, consequentiae}

Die samehang van logika en taalbegrip word in opvolging van Augustinus beklemtoon deur Anicius Manlius Severinus Boethius (circa 476 n.C.-525 n.C.), die mees gevolgryke Latynse logikus van die post-Romeinse en Carolingiese periodes: 'Die hele kuns van logika is verweef met taal' (Boethius 1934:74).

In teenstelling met die waardering vir die grootsheid van sy intellektuele erfenis binne die Middeleeuse navorsing

7.Hierdie beredenering is in die middel-skolastiek van die 13 de eeu breedvoerig heropgeneem in die ontwikkeling van ' $n$ 'teorie van supposisie', waaraan ons heropgeneem in die ontwikkeling van 'n 'teorie van supposisie', waaraan ons
hieronder in die afdelings oor Abelardus en Hispanus breedvoeriger aandag gee; vergelyk Leff (1958:9). 
as sodanig, is die lewe en werk van Boethius buite die spesialisnavorsing en buiten sy bekende De consolatione Philosophiae, betreklik ondergepubliseerd. ${ }^{8}$ Boethius is buite die navorsing nie naastenby so bekend en gepubliseerd as figure soos Augustinus, Petrus Abelardus, Thomas Aquinas of Johannes Duns Skotus nie. Minstens die volgende sou biografies oor Boethius gestel kon word, om daarmee ook in die Afrikaanse taal een van die delikate filosofiese stemme van die post-Romeinse era en vroeg-Middeleeue in skerper lig te bring: Boethius is deur die gevierde Duitse navorser, Martin Grabmann (1909:3, 148), in alle opsigte korrek beskryf as 'der letze Römer und der erste Scholastiker' - die laaste Romein en eerste skolastikus. Boethius is rondom 476 n.C. in senatoriale familieverband gebore, in die tyd toe die laaste Romeinse keiser, Romulus Augustulus, onthef is en die Ostrogote onder leiding van Theoderik reeds beheer oor die grootste gebied van die Suid-Europese deel van die Romeinse Ryk verkry het. Boethius het self konsul onder Theoderik in 510 n.C. geword en is 15 jaar later op grond van beweerde hoogverraad deur Theoderik self terreggestel. Boethius het wesenlik net een, hoewel 'n enorme, intellektuele doelstelling gehad: omdat hy besef het dat die Romeinse Ryk besig was om finaal in duie te stort, waarskynlik nog in sy eie leeftyd, wou hy die Hellenistiese filosofiese erfenis (en die RomeinsPatristiese kommentare daarop) in Latyn vertaal, redigeer en in Latyn herkommentarieer vir opvolgende geslagte. Sy Carolingiese en skolastiese opvolgers is ten diepste geraak deur hierdie (onvoltooide) taak. Middeleeuse denkers sou op Boethius se vertalings, redigerings en kommentare aangewese wees vir feitlik alle inligting rakende antieke logika, en ook fundamentele kwessies met betrekking tot antieke wiskunde en musiekteorie. Waar Aristoteles in die Patristiek grootliks verbygegaan is en gefokus is op Plato en die Stoïsyne (grootliks omdat Aristoteles geleer het dat die fisiese werklikheid van 'ewigheid' af was en goddelike voorsienigheid en die onsterflikheid van die siel afgewys het, dus te pagaans was om in die opkomende Patristiek vanaf die 2de eeu geakkommodeer te word), is daar onder nieChristelike denkers juis gefokus op Aristoteles. Dit was veral die Neoplatonis Plotinus, rondom die helfte van die 3de eeu, en sy student Porphyreus (wat 10 kommentare op Aristoteles geskryf het) wat ' $n$ Aristoteliese stemming, hoe sydelings en nie-gelyklopend met die stabiele Platoniese tradisie ook al, in die Patristiese en laat-Romeinse eras bestendig het.

Boethius vind juis by hierdie tradisie aansluiting en daarin vestig die sonderlinge kwaliteit van sy bydrae. Sy vertalings van Aristoteles se werke in Latyn sou die basis vorm van die post-Carolingiese en vroeg-skolastiese nadering tot Aristoteles, met inbegrip van die monumentale werk wat die Arabiese denkers Avicenna en Averroes vanaf die 10de eeu gelewer het om Aristoteles vanuit Arabies vir die

8.Die Internasionale Boethius Vereniging (http://www9.georgetown.edu/faculty/ jod/boethius.society.html) beywer sigself onder meer juis vir die bestendiging
van Boethius se erfenisprofiel buite die gespesialiseerde navorsing. Bostaande ekskurs is grootliks gebaseer op die outeur se ongepubliseerde lesingnotas en die relevante passasies in Grabmann (1909), Chadwick (1981) en Luscombe (2004). Le ook daarop dat Boethius se vertalings van Aristoteles se werke deur die beroemd Middeleeuse vertalingspesialis Lorenzo Minio-Paluello in Volumes I, II, III, V en VI van Aristoteles Latinus (Brill, Leiden) geredigeer en herbundel is. Vir die mees uitstaande werk rakende metodologiese- en resepsiekwessies in die Boethius navorsing, sien juis daarby Minio-Paluello (1972). opkomende universiteitswese in Wes-Europa beskikbaar te stel: 'n saak wat telkens deur voetnotas in hierdie artikel beklemtoon sal word. Onder Boethius se mees gevierde projekte tel sy vertalings van Aristoteles se werke in formele logika in Latyn: Categoriae, De Interpretatione, Topica, De sophisticis elenchis, Analitica Priora en Analitica Posteriora. Hy het ook grondige kommentare geskryf oor Categoriae, De Interpretatione (twee maal), Topica en Cicero se gelyknamige teks. Verder het hy Porphyreus se inleiding tot Aristoteles se logika, Isagoge, vertaal en twee maal gekommentarieer. Sy eie werk bestryk De divisione, De hypotheticis syllogismis, De syllogismo categorico, De topicis differentiis, Opuscula Sacra en De consolatione Philosophiae.

Boethius se nalatanskap het die laat-9de eeu ongelukkig gefragmenteerd bereik en nie al sy werk het die Carolingiese periode oorleef nie. Sy vertaling van Analitica Posteriora en sy kommentaar op Topica het glad nie oorleef nie, sy vertaling van Categoriae het eers teen die einde van die 9de eeu begin sirkuleer en sy vertaling van Topica het eers in die 12 de eeu begin sirkuleer. Dit wat wel oorleef het en vir Carolingiese, post-Carolingiese en vroeg-skolastiese denkers beskikbaar was, het as die logica vetus (die 'ou logika') bekend gestaan: daarmee is studente vanaf die 10de eeu in formele logika (pertinent Aristotelies en vir eeue daarna die hoofdissipline in filosofie) onderrig en is die gelatiniseerde terminologie van Boethius konsekwent gebruik. Boethius was dus die Latynse oordraer van die Griekse Aristoteles na die Middeleeue, met inbegrip van die latere Arabiese inset vanaf Avicenna en Averroes (wat 'n afsonderlike, hoewel uiters belangrike tema ten opsigte van Middeleeus-Aristoteliese resepsiekwessies is).

Sy laaste werk, De consolatione Philosophiae, is buite die nisnavorsing ook sy bekendste werk. Boethius het die werk vanuit die tronk, afwagtend op teregstelling, geskryf. Hier word hy besoek deur Filosofie, 'n pragtige ou dame (dieselfde dame wat aan Sokrates verskyn het in Plato se Crito en wie ook ander martelare van die filosofie, onder meer Anaxagoras en Seneca, in hulle laaste dae vertroos het). Boethius konstateer sy onskuld en bely sy angs vir en vernaamlik voor die dood voor Filosofie. Sy dring daarop aan dat hy sy gedagtes opwentel na 'n werklikheid anderkant sintuig en materie. Saam ondersoek Boethius en Filosofie dan die verhouding tussen Lot en Voorsienigheid. Moes vertroosting daarin gevind word, soos die Stoïsyne geleer het, dat die werklikheid deur noodwendigheid en 'n skeut lotgeval beheer word? Filosofie dring dan daarop aan dat Boethius Lot nie sal blameer vir die verlies aan die eer, mag en plesier wat hy as konsul geniet het nie, omdat 'n wyse mens hierdie sake nooit hoog behoort te ag nie. Dit is, inderdaad soos die Stoïsyne geleer het, onvolmaakte en tydelike dinge. Wat nie verander nie, is die hoogste Goed, en dit is God. Lot is onderworpe aan Voorsienigheid, wat die heelal regeer en reguleer deur 'n liefde fortiter ac suaviter, sterk en soet (vgl. die vroulike wysheidsbetoog in Spreuke 8). God ken alle dinge terselfdertyd, sonder om vrye wil te vernietig. 
Heelwat van Boethius se voorafgaande werke verskaf die filosofiese impetus aan De consolatione Philosophiae: die beginsel dat die eerste beginsel (of 'eerste beweger', in Aristoteliese taal) van alle dinge goed is, die verhouding tussen noodwendigheid en Goddelike voorsienigheid, en so meer. Tematies was die latere Middeleeue gepreokkupeer (vgl. Bosley \& Tweedale 2004:xxi) met temas uit De consolatione: lotgeval, noodwendigheid of determinisme, kans, vrye wil, die verhouding tussen universaliteit en partikulariteit, en die vraag na die hoogste goed. Vanaf die 9de eeu het 'n ryke argief van kommentaar op hierdie teks ontwikkel; Koning Alfred het dit in Ou Engels laat vertaal in die 9de eeu, en Chaucer het dit met ' $n$ vertaling opgevolg in die 14de eeu. Die werk het oorleef in ongeveer 400 mansukripte en word, soos die Confessiones van Augustinus, vandag nog herdruk (vgl. Frakes 1988:91).

Boethius het dus feitlik al die boeke in die Aristoteliese logika-korpus vertaal en dus ook vertaalwerk en kommentaarwerk gelewer ten opsigte van Aristoteles se twee belangrikste eksponente in die Patristiese periode, te wete die Neoplatoniste Plotinus en Porphyreus, met besondere verwysing na laasgenoemde se Isagoge. Porphyreus, student en biograaf van Plotinus, het Aristoteles se logika in die kurrikulum van die Neoplatoniese skole ingevoer en sy Isagoge is hiervoor as inleidingsteks gebruik: danksy die vertaling daarvan in Latyn deur Boethius, het hierdie teks die posisie as standaardteks tot diep in die Middeleeue gehandhaaf (vgl. Sweeney 2006:15). 'n Sentrale element van Porphyreus se Isagoge is die 'teorie van praedicabiles' of, die soorte verhoudinge waarin ' $n$ predikaat tot 'n subjek mag staan. Porphyreus lys vyf sodanige praedicabiles: species, genus, differentia, proprium en accidit. Al hierdie terme kom in Aristoteles se Categoriae, in die gedaante van die teorie van die '10 kategorieë' (kyk voetnota 12) voor, hoewel die teorie van praedicabiles van die teorie van die kategorieë, ook met inbegrip van wesenlike ooreenkomste, verskil.

'Steffi is 'n Duitse herdershond' dui die species aan waartoe Steffi behoort. 'Steffi is ' $n$ hond' dui die genus aan waartoe Steffi behoort. Differentia dui die verskil van species binne genus aan: byvoorbeeld, 'Steffi vertoon meer as enige ander hond soos ' $\mathrm{n}$ wolf'. ${ }^{10}$ Proprium is 'n eienskap wat kenmerkend, hoewel nie definïerend van nie, die spesifieke species is: byvoorbeeld, 'Duitse herdershonde is uitstekende waghonde' ${ }^{\prime 1}$. Accidit is 'n predikaat wat tot 'n bepaalde individu mag behoort, sonder dat die individu daarmee gepredetermineer word, byvoorbeeld: 'Steffi het, anders as ander vroulike Duitse herdershonde, 'n maanhaarkraag.' Dit onderskei Steffi van ander individue in haar species, maar dit kan nie (anders as species, genus, differentia en proprium) voorsien word nie.

9.In ooreenstemming met die gangbare werkswyse in Middeleeuse navorsing, word die Latynse vertalings van Griekse konsepte konsekwent gebruik, of minstens naas die Grieks verskaf. Hiervoor was en is Boethius se latiniserings van Griekse konsepte onontbeerlik.

10.Mense, was die gangbare Middeleeuse verduideliking, vorm ' $n$ species van die genus 'animal', afgemerk met die differentia 'rational', dus 'animal rational'.

11.Aquinas het dit eeue later verduidelik as sou die verstaan van ' $n$ grap ' $n$ proprium van mense wees - slegs mense lag vir' $n$ grap, maar nie alle mense lag vir dieselfde soort grap nie, sommige mense lag glad nie en sommige mense verstaan geen grap nie.
Die teorie van praedicabiles stel ons in staat om 'n rangorde binne kategorieë te konstrueer. Die onderskeid tussen genus en species is relatief: ' $n$ Species relatief tot 'n meerdere genus is ' $\mathrm{n}$ genus relatief tot ' $\mathrm{n}$ mindere species. En tog is daar buitengewone genera wat nie species van enige meerdere genus is nie. Aristoteles se 10 kategorieë of praedicamenta ${ }^{12}$ is nie species van 'n hoër genus soos 'syn' nie. Sou ons die die kategorie van Ousia, of in Latyn Substantia, vanuit die antepraedicamenta se logiese diktaat as ' $n$ basiese gegewe neem, sou ons twee genera daaruit kon ontleen, naamlik liggaam en gees, deur die differentia 'materieel' of 'immaterieel' onderskeidelik daarop toe te pas. Vanuit die genus 'liggaam', kan twee verdere genera afgelei word, naamlik 'lewende wesens' en 'minerale', deur die differentia 'animus' en 'non animus' daarop toe te pas. Die genus van 'lewende wesens' sal deur 'n soortgelyke fissie of onderverdeling die genera 'plant' en 'dier' genereer en die genus 'dier' sal met die differentia 'rational' die finale species 'mens' produseer, wat weer die individue Petrus, Paulus en Johannes sal insluit. ${ }^{13}$

In sy Isagoge gebruik Porphyreus hierdie vertakkende strategie om drie wesenlike vrae aangaande species en genera te formuleer. Species en genera is nie individuele entiteite soos Petrus, Paulus of Johannes nie: species en genera is universeel in ' $n$ bepaalde sin. (1) Bestaan species en genera dan buite die verstand? (2) Is species en genera dan liggaamlik-gebonde of liggaamlik-ongebonde? (3) Indien species en genera liggaamlik-ongebonde is, bestaan dit dan in dinge wat deur die sintuie waarneembaar is, of bestaan dit dan onafhanklik van sintuiglike waarneming? Porphyreus het hierdie wesenlike vrae nie self beantwoord nie, maar implisiet aan Boethius en die tradisie daarna toevertrou. Hierdie vrae sou die agenda opstel vir talle Middeleeuse strydgesprekke en die gekanoniseerde bundel stellings vir die probleem van universeles daarstel.

12.Aristoteles se bekende 10 kategorieë of praedicamenta behels enige iets wat die subjek of predikaat van ' $n$ stelling kan wees. In Categoriae (1995:3-25; vgl. Ackrill [1963:60ev]) argumenteer Aristoteles dat die voorwardes vir die praedicamenta, [1963:60ev]) argumenteer Aristoteles dat die voorwaardes vir die praedicamenta, die antepraedicamenta, ' $n$ vierledige struktuur behels, wat self ontstaan vanuit
twee basiese spraakvorme, of spraak-as-syn, naamlik eenvoudig (bv. 'die vrou') of twee basiese spraakvorme, of spraak-as-syn, naamlik eenvoudig (bv. 'die vrou') of kompleks (bv. 'die vrou loop'), terwyl slegs laasgenoemde komplekse spraakvorme
waar of vals kan wees. Vanuit alle dinge wat bestaan, is (1) sommige dinge waar of vals kan wees. Vanuit alle dinge wat bestaan, is (1) sommige dinge
predikate van ' $n$ subjek, maar nie teenwoordig in ' $n$ subjek nie; (2) sommige dinge predikate van ' $n$ subjek, maar nie teenwoordig in ' $n$ subjek nie; (2) sommige dinge
in ' $n$ subjek, maar nie predikate van ' $n$ subjek nie; (3) sommige dinge in sowel ' $n$ in ' $n$ subjek, maar nie predikate van ' $n$ subjek nie; (3) sommige dinge in sowel '
subjek as ' $n$ predikaat van die subjek; en (4) sommige dinge nie in ' $n$ subjek of in enige predikate van die subjek nie. Die 10 praedicamenta val voorwaardelik op die antepraedicamenta terug (Boethius se Latynse woordvertalings word telkens onderstreep na die oorspronklike Griekse woord verskaf): (1) Ousia/Substantia (of tode ti of ti esti - substansie, 'dit' of 'wat dit is'), wat nie gepredikeer kan word ten aansien van enige objek nie en wat nie 'in' enige objek is nie (bv. 'vrou', 'Mary' 'Mary is ' $n$ vrou'); (2) Poson/Quantitas (kwantiteit, 'hoeveel'), wat die verlengstuk van die objek, afgebroke of voortgaande, aandui (bv. 'meter', 'ligjaar', 'ewigheid'); (3) Poin/Qualitas (kwaliteit 'watter soort') wat die 'mard ', 'ngaar', 'ewigheid') (3) Poion/Qualitas (kwaliteit, 'watter soort'), wat die aard van ' $n$ objek determineer (bv. 'blonde hare', 'groenogig'); (4) Pros ti / Ad aliquid (relasie, 'waarvan') wat die verhouding van enige objek tot ' $n$ ander objek beskryf (bv. 'groter', 'dubbeld'); (5) Pou / Ubi (plek, ligging, 'waar'), wat die objek in terme van die geometries omgewing beskryf (bv. 'in die lesinglokaal'); (6) Pote/Quando (tyd, 'wanneer'), wat die objek se posisie in terme van ' $n$ gebeure, afgebroke of voortgaande, beskry (bv. 'gister'); (7) Keisthai/Positio (posisie, houding, 'hoe'), wat die objek se posisie aan die einde van ' $n$ korresponderende handeling aandui (bv. 'sit', 'staan'); (8) Echein/Habere (toestand, 'om te besit'), wat die objek se toestand aan die einde van ' $n$ affekterende handeling aandui (bv. 'moeg' of 'gewond'); (9) Poiein/Facere (handeling, 'om te doen'), wat ' $n$ verandering in ' $n$ objek aandui ('brand', of eenvoudig 'maak'); en (10) Pasgein/Pati (die passief van poiein, 'om mee gehandel te word'), wat die resepsie van verandering in ' $\mathrm{n}$ objek aandui (bv. 'om gebrand te word', of 'gemaak te word'). Hierdie logiese sisteem van die ordening van die verhouding tussen spraak en werklikheid was die wesenlike instrument wat Middeleeuse studente, in besonder na Boethius, tot hulle beskikking gehad het om die filosofiese temas warmee hulle besig was, te orden. Hierdie terme, in die om die filosofiese temas waarmee hulle besig was, te orden. Hierdie terme, in die Latyn, kom tot lank na Descartes en nog later na Hume, nog konsekwent in die filosofiese diskoers van die moderne voor. Trouens, die filosofiese diskoers van die
moderne het alles aan hierdie begrippeskat te danke.

13. Hierdie vertakkende ordening van dinge word diagrammaties ' $n$ 'Porphyreus boom' genoem. 
Boethius (1891:835A $)^{14}$ het inderdaad self op hierdie vrae gereageer: species en genera bestaan syns insiens buite die verstand, species en genera is liggaamlik-ongebonde en species en genera is nie skeibaar buiten in die verstand van die individu nie. 'n Species of genus word soortgelyk geabstraheer vanuit partikulieres, net soos wat ons die soortgenootlikheid van die mensheid of similitudo humanitatis vanuit individuele mense abstraherend konstrueer. Boethius (1891:835A) beskou dit as ' $\mathrm{n}$ Aristoteliese greep, hoewel dit nie vir die doeleindes van formele logika nodig is om die bekende Platoniese Vormtesis van 'universeles wat in afsondering bestaan', uit te rangeer nie. ${ }^{15}$ Boethius se kommentare op Categoriae en De Interpretatione vertoon in hierdie konteks ' $\mathrm{n}$ kennis van Stoïsynse logika, wat hy nie as 'n korrektief op Aristoteles lees, kommentarieer of vertaal nie (vgl. Kenny 2005:121).

Boethius (1877:II, 208.1-4) argumenteer onder meer dat die Stoïsyne toekomstige kontingentes misverstaan het: As $p$ 'n toekomsverwysde proposisie oor ' $n$ kontingente saak is, is óf $p$ óf nie- $p$ waar, maar nie $p$ of nie- $p$ hoef noodwendig waar te wees nie. Om Aristoteles se bekende 'see-oorlog metafoor' in De Interpretatione 9 as verwysing te gebruik: 'Of daar is more 'n see-oorlog of daar is more nie 'n see-oorlog nie, is waar', maar nie een van 'Daar sal more 'n see-oorlog wees' of 'Daar sal more nie 'n see-oorlog wees nie' is vandag noodwendig waar nie. Die Stoïsyne se opvatting dat Aristoteles sou bedoel het dat sulke toekomstige kontingentes nie waar óf vals is nie, is verkeerd, omdat dit by die begrip 'nie noodwendig waar nie' verbygaan. Boethius se kommentaar op De Interpretatione 9, met inbegrip van sy kennis van die Stoïsynse posisie, is 'n goeie voorbeeld van die wyse waarop hy Aristoteles polemies kommentarieer en vir die Carolingiese periode beskikbaar stel (vgl. Kretzmann 1998:49-52). Dit is ook 'n goeie voorbeeld van die wyse waarop taalgebruik logiese posisionering bepaal.

Afgesien van bogenoemde voorbeelde van Boethius se kommentaar op Porphyreus en Aristoteles, is Boethius se twee werke oor sillogistiese argumentering, De hypotheticis syllogismis en De syllogismo categorico, binne die konteks van die verhouding taalbegrip-logika, betekenisvol. Boethius maak ' $n$ onderskeid tussen kategoriese sillogismes en hipotetiese sillogismes. ' $n$ Kategoriese sillogisme is 'n soort argument wat bestaan uit presies drie kategoriese stellings (twee premisses en 'n konklusie) waarin daar 'n somtaal van presies drie kategoriese terme bestaan, waarvan elkeen presies twee keer gebruik word, byvoorbeeld: alle vinke is voëls, all e voëls is diere, dus, alle vinke is diere. 'n Hipotetiese sillogisme moet minstens een hipotetiese premisse bevat: As $p>q$; as $q>r$; (as $p ; q) p>r$; 'as dit reën' > 'sal ek nie gholf speel nie'; 'as ek nie gholf speel nie' > 'vat ek nie my gholfsak nie';

14.Vergelyk in die sekondêre literatuur in besonder Bosley en Tweedale (2004:251260, 317-319); Copleston (1972:54-55, in ' $n$ baie kort en onsimpatieke oorsig, betreklik tiperend van die wyse waarop Boethius in inleidingswerke hantee word); Kenny (2005:119-122); Luscombe (2004:16-23) en Marenbon (2007:1112 resente literatuur). Vergelyk daarby die uitstekende inleidingswerk van Stewart et al. (1973).

15.In Plato se filosofie is die Vorme die ewige, onveranderlike argetipes waarop die werklikheid van materie gemodelleer is en wat slegs geken kan word vanuit abstraherend-intellektuele denke of intuïsie. 'as dit reën' > 'vat ek nie my gholfsak nie'. Meer taalfilosofies: 'n hipotetiese sillogisme bevat 'n hipotetiese proposisie gekonstrueer deur kategoriese proposisies deur middel van die taalverbindings 'as', 'of' en 'aangesien'.

Sommige hipotetiese sillogismes bevat kategoriese premisses sowel as hipotetiese premisses, waarvan die bekendste die modus ponendo ponens, of verkort net modus ponens (alreeds gevestig in Stoïsynse logika) is, byvoorbeeld: 'as dit dag is, skyn die son, maar dit is dag, dus skyn die son'. Dit is 'n eenvoudige argument, waar die geaffirmeerde self weer affirmeer: as $p>q$. Dit is $p$; dus $q$.

Boethius fokus egter kenmerkend polemies op sillogismes waar sowel die premisses as die konklusie hipoteties is, byvoorbeeld: As dit $p$ is, is dit $q$; as dit $q$ is, is dit $r$; dus, as dit $p$ is, is dit $r$. In De Topicis Differrentiis (Boethius 1978) ontwikkel hy logies-skematiese strukture wat sowel negatiewe; as affirmatiewe; as konjunktiewe (anders as 'as') premisses insluit, byvoorbeeld: dit is óf dag, óf dit is nag; $p /$ nie- $p[r]$. Boethius argumenteer dat hipotetiese sillogismes taalkundig op kategoriese sillogismes parasiteer, omdat hipotetiese premisses kategoriese premisses as die konstituente daarvan het en van kategoriese sillogismes afhanklik is om die waarheidsaanspraak van die tersaaklike hipotetiese premisse te begrond. Ook in De Topicis Differrentiis vind Boethius dus weer duidelik aansluiting by Aristoteles teen die Stoïsyne en hierdie keer oor die verhouding tussen predikatiewe en proposionele logika, wat deur en deur met taalbegrip te make het.

In sy kritiese uiteensetting van hipotetiese sillogismes maak Boethius (1978:45ev) 'n belangrike onderskeid tussen twee soort hipotetiese stellings. Eerstens ontwikkel hy die begrip consequentia as ' $\mathrm{n}$ aanduiding van ' $\mathrm{n}$ 'outentieke hipotetiese stelling', een waarvan die waarheid aldan nie, uiteindelik sal moet manifesteer. Dan argumenteer hy dat sommige consequentiae geen noodwendige verbintenis tussen die antesedent en die consequentia of gevolg daarvan aandui nie; byvoorbeeld, 'Omdat vuur warm is, is die hemelboog rond' ${ }^{\prime 16}$. Ander consequentiae weer, volg noodwendig vanuit die antesedent: byvoorbeeld, 'Omdat vuur warm is, is daar kole $^{\prime 17}$.

Boethius (1978:61ev) stel vanuit hierdie onderskeid dan 'n taalanalitiese proposisiekritiek op: ware consequentiae, in beide gevalle, kan afgelei word vanuit 'n sisteem van superieure universele proposisies, wat Boethius loci noem. Hierdie loci stel ons in staat om die (gestruktureerde) waarheid aangaande enige proposisie te begryp. 'n Taalhandeling, naamlik die beskrywing van die loci, wat Boethius (1978:64ev) uiters gedetailleerd uitwerk, word dus die meehanger van logiese analise. Sowel taalbegrip as logiese analise speel ' $n$ rol in die herkennning van die waarheidsaanspraak van 'n proposisie.

16.Dit kom ooreen met wat moderne logici ' $n$ 'materiële implikasie' sou noem. Boethius se eiegemaakte begrip is consequentia secundum accidens.

17.Dit kom nie alleen ooreen met wat moderne logici ' $n$ 'formele implikasie' sou noem nie, maar ook daardie eietydse hipotetiese stellinge waarvan die waarheidsaanspraak deur wetenskaplike ondersoek begrond word, of kan word. 
Boethius se nalatenskap as vertaler, kommentator en Aristoteliaanse logikus, het die taalgenootlike dekor verskaf aan die hand waarvan die studie van logika in die Carolingiese en post-Carolingiese eras bestendig kon word, tot en met die ruimer beskikbaarmaking van die Aristoteliese korpus in die middel-skolastiek van die 13de eeu. As die ou logika of logica vetus het dit die weg berei vir die nuwe logika of logica novus wat in die opkomende universiteitswese vanaf die laat-12de eeu onderrig en gepraktiseer sou word. Die logica vetus kulmineer in besonder in die werk van Petrus Abelardus, die skarnierfiguur tussen die Carolingiese en skolastiese periodes. In sy werk sou die reeds-omlynde samehang tussen logika en taalbegrip, soos sigbaar vanaf Augustinus na Boethius, nog skerper omlyn word.

\section{Petrus Abelardus: Nomen, res, dictum}

Petrus Abelardus (1079-1142), ${ }^{18}$ naas Anselmus die invloedrykste Westerse filosoof in die post-Carolingiese periode, se eksponerende werk vanuit die logica vetus het hom as 'n mede-wegbereider vir die volle rehabilitering van Aristoteles in die vroeë skolastiek van die laat $12 \mathrm{de}$ eeu en veral die hoë skolastiek van die 13de en 14de eeu gevestig, histories bykans parallel met die toenemende stroom van Latynse vertalings van die Arabiese ${ }^{19}$ vertalings van, en kommentare op, die Griekse tekste. Abelardus se bydrae tot die Westerse register, spesifiek as kommentator en interpreteerder van sy besondere ideehistoriese tradisie, juis in die afwesigheid van 'n werkbare Aristoteliese korpus, kan trouens moeilik oorskat word..$^{20}$ Die talle kontemporêre monografieë ${ }^{21}$ wat oor Abelardus beskikbaar is, beklemtoon sy bydraes in logika, etiek, metafisika en taalfilosofie via sy unieke nominalistiese en dialektiese posisies.

18. Abelardus, soos al sy post-Carolingiese tydgenote, het beperkte en gefragmenteerde toegang tot die Aristoteliese logika gehad, gegewe sy lewensdatering in die toegang tot die Aristoteliese logika gehad, gegewe sy lewensdatering in die onmiddellike nagloed van die Carolingiese Renaissance, waar skaars begin is met die rehabilitering van die Hellenisties-Romeinse erfenisse, na net minder as eeue sedert die eerste Barbaarse inval in Rome in 410 n.C. Dit sou trouens na Abelardus nog logica vetus van Boethius en die oordrag vanaf die Arabiese denkers Avicenna en Averroes, gerehabiliteer sou word van die Platonies-gedrewe onderdrukking van Aristoteliese premisses in die Westerse kerk van die post-Romeinse en Bisantynse periodes (vgl. die gesaghebbende analise van Klibansky [1982:13ev]). Boethius se erfenis ten aansien van die logica vetus was juis om hierdie rede deurslaggewend belangrik. Daarsonder sou Abelardus nie sy rol as skarnierfiguur tussen die Carolingiese periode en die vroeë skolastiek kon vervul nie.

19. Dit is nodig om weer te beklemtoon dat die beskikbaarstelling van die Hellenistiese erfenis, veral met betrekking tot die Aristoteliese tekste, nie gedurende die Carolin, Carolingiese Renaissance (buiten Boethius se reeds beskikbare vertalings, hoewel no eeu in Arabies na die Westerse filosowe van die 10de eeu en later deurgesypel het. Latynse vertalings van die Griekse tekste, buiten die logica vetus, was dus aanvanklik gebaseer op die Arabiese vertalings van die Griekste tekste. Die aanvanklik gebaseer op die Arabiese vertalings van die Griekste tekste. Die
rehabilitasie van Aristoteles in die latere Middeleeue en Italiaanse Renaissance is, naas die nalatenskap van Boethius met die logica vetus, volledig toe te skryf aan die vertalings en kommentare van Avicenna en Averroes (vir 'n uitgebreide bespreking van hierdie belangrike resepsiekwessie, kyk Copleston 1972:104-124; kyk ook Armstrong 1976:iv).

20.Kyk Brower en Guilfoy (2004), Clanchy (1999:80-85), Wilks (2008), Wadell (2008) Sweeney (2006), Luscombe (1992:127-138), Mews (2001) en Mews en Jolivet (1990:135-140) vir relatief resente waarderings.

21.Vir die mees resente kommentare, geannoteerde vertalings van primêre tekste en monografiese werke in die Abelardus-navorsing, kyk Mews (2001), Spade (1995), Clanchy (1999), Marenbon (1999), Brower en Guilfoy (2004 ['n uitstekende bloemlesing]) en Wadell (2008). Die ouer 20de-eeuse werke wat status geniet as standaardverwysings in die Abelardus-literatuur, is McCabe (1972 [1901]), as standaardverwysings in die Abelardus-literatuur, is McCabe (1972 [1901]),
Dahmen (1906), Murray (1967), Luscombe (1969), Weingart (1970) en Tweedale Dahmen $(1976)$.
Abelardus se bekendste tekste val in drie afdelings uiteen: (1) sy 'dialektiek' ('n bundeling van logika, taalfilosofie en metafisika), opgeneem in sy twee beroemdste werke, Logica Ingredientibus en Dialectica ${ }^{22}$, met die vier kleiner werke in logika daaronder gegroepeer, naamlik Introductiones parvulorum, Logica nostrorum petitioni sociorum, Tractatus de intellectibus en Sententiae secundum Magistrum Petrum; (2) sy etiek, opgeneem in Ethica seu Scito teipsum en sy kontroversiële dialoog tussen 'n Jood en Christen, Collationes (later gesirkuleer as Dialogus inter Philosophum, Iudaeum et Christianum; en (3) sy filosofiese teologie, opgeneem in Theologia 'Summi Boni', Theologia Christiana en die laat Theologia 'Scholarium'. ${ }^{23}$ Hierdie laaste drie werke is in die resepsiegeskiedenis berug omdat elkeen talle keer herskryf is in Abelardus se pogings om sy gedagtes meer ortodoks in te kleur, in aanvaarbare kerklike terminologie te herformuleer en sy posisie in die legendariese skermutseling met Bernardus van Clairveaux rakende die talle aanklagte teen die beweerde ketterse kwaliteit van sy nominalisme te bestendig. ${ }^{24}$

Abelardus tree vanuit dieoortuiging van diestrengesamehang of konstellasie van taalbegrip en logika met die logica vetus in gerig. Hy gebruik die begrip 'dialektiek' wanneer hy logika in gedagte het en die logica vetus as sodanig kommentarieer - vandaar die titel van sy beroemdste werk, Dialectica. Hy staan in die tematiese verlengstuk van Augustinus en Boethius se posisies wanneer hy in die middelgedeelte van Dialectica sonder voorbehoud beweer: 'logika is ars sermocinalis', 'n taalkundige dissipline (Abelardus 1971:148). Logika en taalbegrip kan op geen wyse van mekaar geskei word nie. Soos grammatika, bestryk logika woorde; maar dan juis betekenisstigtende woorde (sermones) en nie bloot klanke (voces) nie. Sy analise van sermones en sy bydrae tot die konstellasie taalbegrip-logika val in vyf fasette uiteen. ${ }^{25}$

Eerstens bepleit Abelardus 'n grammatikaal-logiese beweging vanaf eksistensiale proposisies na gekwantifiseerde proposisies. Dit doen Abelardus deur te beklemtoon dat 'n standhoudende logika met 'n standhoudende uiteensetting van die grammatikale dele van spraak, veral met betrekking tot selfstandige naamwoorde en werkwoorde, moet begin. Aristoteles se posisie was dat 'n onderskeid getref moet word tussen selfstandige naamwoorde en werkwoorde omdat laasgenoemde altyd 'n temporele aanduiding bevat. Abelardus (1971:149ev) was vanuit die logica vetus bewus van hierdie posisie en gee toe dat werkwoorde altyd tydsbepaald is, maar argumenteer dat ook selfstandige naamwoorde implisiete temporele aanduidings bevat. Subjekpredikate

22.Die datering van Abelardus se tekste is al vir baie eeue' $n$ kontroversiële kwessie in die navorsing, omdat Abelardus tot en met sy dood sy eie werk geherredigeer en gedeeltes selfs volledig herskryf het, wat daartoe gelei het dat verskeie en verskillende edisies van ' $n$ bepaalde werk in omloop was en steeds is (Mews 1986:75; kyk McCabe 1972 [1901]:54:54).

23.Kyk Beukes (2011) vir ' $n$ resente analise van hierdie werk op die marges van die oeuvre.

24.Vir kritiese rekenskap van die uiters problematiese redaksie- en resepsiegeskiedenis van hierdie primêre tekste, kyk Mews (1986:73v); kyk ook Clanchy (1999:21ev), Luscombe (1967:19ev), Marenbon (1999:25ev) en McCabe (1972 [1901]:14).

25.Vergelyk in die sekondêre literatuur in besonder Bosley en Tweedale (2004:378-403); Copleston (1972:80-85); Kenny (2005:123-127); Luscombe (2004:47-56), Marenbon (2007:3703-3800) en Murray (1967:3-25). 
dui hoofsaaklik sake in die teenswoordige tyd aan: 'Sokrates was 'n seun' is logies slegs wanneer Sokrates se subjektiewe, teenswoordige staat een van gevorderde leeftyd is. Indien tyd slegs in die werkwoord opgeneem is, sou dieselfde stelling moes kon lui, "n Seun was Sokrates', wat 'n valse stelling is. Die korrekte korresponderende sin sou moes lui, 'Iets wat 'n seun was, is Sokrates'. Hierdie voorbeeld illustreer die implisiete temporele aanduidings in selfstandige naamwoorde, wat ondersteun word deur 'n logiestoeganklike taalbegrip waar selfstandige naamwoorde met voornaamwoorde vervang word, gevolg deur beskrywende frases, byvoorbeeld 'Die lig skyn in', wat logies herskryf sou kon word as 'Iets wat lig is, skyn in'. Uitsluitend kenmerkend van werkwoorde is dus nie dat dit tydsbepaald is nie (want selfstandige naamwoorde is dit dan implisiet ook) maar dat werkwoorde sinskonstruksies moontlik maak. Sonder werkwoorde is daar geen sin nie en ook geen sin in die sin van betekenis nie. Daar kan wel logiese sinne wees sonder selfstandige naamwoorde, soos by imperatiewe of eenvoudige indikatiewe ('Kom hier!' of 'Dit is koud'), maar geen sin sonder werkwoorde nie (Abelardus 1971:149). Aristoteles se posisie was dat die gestandaardiseerde sinskonstruksie 's $=p^{\prime}$ sou moes wees. Hoewel 'n sin soos 'Sokrates drink' nie die oorganklike copula $(=)$ bevat nie, argumenteer Aristoteles dat die sin altyd herskryf sou kon word as 'Sokrates is 'n drinker'. Abelardus (1971:138) daarenteen, argumenteer dat die copula $(=)$ 'n eenvoudig verhelderende funksie verrig ten opsigte van 'n verbindingsfunksie wat reeds eksplisiet in elke werkwoord aanwesig is: '.. is ' $n$ man' is reeds 'n eenheid, 'n enkelwerkwoord, as sodanig 'is-' $n$-man'. Die werkwoord 'om te wees' of 'is' of est, word nie bloot gebruik as 'n verbinding tussen die subjek en predikaat nie, maar ook om 'bestaan' aan te dui. Abelardus beskou hierdie semantiese potensialiteit as wesenlik: est kan in 'n sin verskyn as verbonde aan 'n subjek (Socrates est) of as ' $\mathrm{n}$ derde element (Socrates est homo). In laasgenoemde geval dui est nie 'bestaan' aan nie ${ }^{26}$ en enige toegewing aan die pleidooi dat 'bestaan' wel deur est aangedui word, kan ondermyn word deur est homo as est-homo, as 'n eenheid, aan te dui. "n Vader bestaan' moet daarom nie verstaan word as sou "n vader' vir enige iets staan nie; die sin beteken eintlik 'iets is 'n vader'. 'Bestaan' val dan geheel weg as predikaat en word vervang deur ' $n$ kwantifiseerder en 'n werkwoord. ${ }^{27}$

Naas die grammatikaal-logiese beweging vanaf eksistensiale proposisies na gekwantifiseerde proposisies, fokus Abelardus in Logica Ingredientibus (1919:20) tweedens op die probleem van universeles, wat inderdaad een van die sentrale filosofiese probleemstellinge deur geheel die Middeleeue was (vgl. Bosley \& Tweedale 2004:341-344; Dronke 1988:13-17). Onoortuigd deur die uiteenlopende teoretiese posisies van beide sy twee vroegste leermeesters, die nominalis Roskelin

26.Abelardus (1971:150) illustreer met die stelling Chimera est opinabilis: 'n Chimera (' $n$ Hellenisties-mitologiese monster) is bedinkbaar. Dit beteken nie dat ' $n$ chimera bestaan nie.

27.Abelardus se logiese innovering deur grammatikaal-logies vanaf eksistensiale proposisies na gekwantifiseerde proposisies te beweeg, is teologies uiteraard gevolgryk. Dit is trouens deur Bertrand Russell (1961:752) beskryf as die enkele belangrikste teenvoeter vanuit die Middeleeue vir Anselmus se ontologiese belangrikste teenvoeter vanuit die Middeleeue vir Anselmus se ontologiese
argument vir God se bestaan en het skerp nawerking geniet in die moderne logika van Gottlob Frege in die 19de eeu. en die realis Willem van Champeaux, bepleit Abelardus (1919:25ev) 'n dialektiese middeweg tussen nominalisme en realisme. Enersyds beskou Abelardus die nominalistiese posisie as absurd: Om te beweer dat Johannes en Paulus niks in gemeen het buiten die naam of noemer 'mens' nie, terwyl die noemer op elkeen betrekking geniet juis op sterkte van objektiewe ooreenkomste, is 'n logies onhoudbare posisie. Andersyds is dit ewe problematies om na die aanspraak van die realistiese posisie te beweer dat daar 'n substansieentititeit, in hierdie geval die spesie homo sapiens, is wat volledig teenwoordig is in een en elke individu: dit sou beteken dat Johannes volledig identies aan Paulus is en op twee plekke gelyktydig sou moes wees. 'n Ooreenkoms tussen mense is nie iets substansieels of partikulier soos ' $n$ mens nie, terwyl slegs ' $n$ mens, oftewel individuele, partikuliere mense bestaan:

Wanneer ons byvoorbeeld beweer dat die ooreenkoms tussen mense nie self 'n mens is nie, moet ons dit vermy om voor te gee dat daar geen ooreenkoms is nie, omdat ons inderwaarheid wil beweer dat die een met die ander ooreenkom - en dit is tog nie self weer 'n mens nie, maar 'n status, 'n toepassing van die begrip "mens" op die partikuliere individu.

(Abelardus 1919:20)

Beide nominalisme en realisme val volgens Abelardus (1919:28) terug op 'n ontoereikende analise van wat dit beteken dat 'n woord 'beteken' of 'verwys'. Woorde verwys op twee wyses: woorde be-teken dinge en woorde verwoord idees. Woorde be-teken dinge juis deur die gepaste idees konseptueel op te roep, daardie konsepte waarmee die verstand die 'dinge in die wêreld bring' (Abelardus 1919:32). Ons eien ons hierdie konsepte toe deur telkens mentale beelde te oorweeg, wat nie gewone beelde is nie (vgl. Abelardus 1971:329). Dit is hierdie konseptuele oorweging van mentale beelde of fantasme ${ }^{28}$ wat ons in staat stel om woorde dinge te laat be-teken en wat klanke betekenisvolle woorde laat word. Daar is geen 'universele mens' los van die universele noemer 'mens' nie; nominalisme is korrek in daardie opsig. Maar die noemer 'mens' is ook nie sonder betekenis nie: dit word in die verstand verbeeld deur ons verstaan van die woord (vanuit die klank) 'mens'. Soos wat die beeldhouer 'n stuk graniet in ' $n$ beeld vormeer, vormeer ons verbeeldende intellek ' $\mathrm{n}$ woord vanuit ' $\mathrm{n}$ klank. Daarom is universeles 'intellektuele skeppings, niks meer of minder nie' (Abelardus 1919:522). Of andersom: woorde be-teken universeles deurdat woorde universele konsepte tot uitdrukking bring. Maar woorde be-teken universeles nie op dieselfde wyse as wat woorde partikulieres in die wêreld be-teken nie. Daarom is daar inderdaad ' $n$ fundamentele grammatikale, logiese en epistemologiese verskil tussen universeles en partikulieres. Daarom is dit nodig dat 'n onderskeid getref moet word tussen wat ' $\mathrm{n}$ woord be-teken en waarvoor dit staan (Abelardus 1971:154). Die woord 'seun' byvoorbeeld, waar en wanneer dit ook al in 'n sinskonstruksie voorkom,

28.' $n$ Fantasm dui in die Middeleeuse filosofie op ' $n$ sintuiglike mentale beeld, wat deur Aristoteles voorgestel is as ' $n$ 'vervoerband' vir denke. In 'n donker klooster, deur Aristoteles voorgestel is as 'n 'vervoerband' vir denke. In "n donker klooster, pal koud, alleen, altyd honger en voortdurend verlangend na intieme menslike aanraking, is die brug vanaf fantasm na fantoom vir "n monnik onafwendbaar: vandaar die teologiese frekwensie van die fantoomdiskoers in die middelskolastiek en die spookagtigheid van die hele monnikebedryf van die latere Middeleeue. 
het dieselfde betekenis: ' $\mathrm{n}$ jong manlike mens. Wanneer die woord 'seun' as subjek in 'n sinskonstruksie gebruik word, soos 'Die seun hardloop skool toe', staan die woord 'seun' vir daardie spesifieke, partikuliere seun wat skool toe hardloop. Maar in ' $\mathrm{n}$ sinskonstruksie waar die woord 'seun' deel uitmaak van die predikaat, soos 'Hierdie ou man was eens 'n seun', staan die woord vir niks. Met ander woorde, die woord 'seun' staan vir iets baie spesifieks in 'n baie spesifieke konteks, 'n partikulariteit, wat eenvoudig getoets kan word deur te vra: Watter seun? Dit is dus 'n logiese taalbegrip wat Abelardus se dialektiese posisie ten opsigte van universaliteit en partikulariteit stu.

Derdens bepleit Abelardus (vgl. 1971:154ev, 1919:275ev) proposisiekritiek, as sulks 'n belangrike voorloper tot Aquinas en die 13de-eeuse skolastiek. Ons moet nie net vra wat individuele woorde beteken nie, maar ook wat hele sinne, stellinge of proposisies beteken. Abelardus (1971:154) definieer 'n proposisie as 'enige verwysing wat waar of vals kan wees'. Ook hier het 'verwysing' 'n dialektiese, dubbele betekenis. ' $n$ Ware proposisie verwys eerstens na ' $n$ ware idee wat in woorde tot uitdrukking gebring word en verwys tweedens na 'dit' wat inderwaarheid 'die geval' of 'die saak' is - wat Abelardus (1971:154) proponit id quod in re est noem. Dit is laasgenoemde wat vir formele logika van belang is - omdat die logikus fokus op die betrokke stand van sake wat logies vloei vanuit 'n voorafgaande stand van sake, eerder as die sekwensie van mentale prosesse in enige subjek se verstand. Die verheldering van die 'stand van sake' (rerum modus habendi se) deur die verwysingsdinamika van 'n proposisie, noem Abelardus (1919:275) die dictum van die proposisie. ' $n$ Dictum is nie 'n feit of gegewe in die wêreld nie, omdat dit iets is wat waar of vals is, of kan wees. Die dictum is waar indien die relevante stand van sake in die wêreld verkry kan word, andersins is dit vals. ${ }^{29}$

Vierdens definieer Abelardus (1919:506) logika as die kuns van die beoordeling en onderskeiding van geldige en ongeldige argumente. Abelardus beperk argumente nie tot sillogismes, soos in die logica vetus nie. Hy fokus op 'n ruimer en meer veralgemenende verstaan van die begrip 'logiese konsekwensie' en gebruik ook nie Boethius se begrip consequentia wanneer hy 'logiese konsekwensie' in gedagte het nie. Hy gebruik wel die begrip consequentia wanneer hy voorwaardelike proposisies in gedagte het: as $p$, dan $r$. Vir 'logiese konsekwensie' gebruik Abelardus die begrip consecutio, wat met 'oordrag' vertaal kan word. Natuurlik is die twee begrippe (consequentia en consecutio) nou verwant, maar nie identies nie: wanneer 'as $p$, dan $r$ ' 'n logiese waarheid is, dan dra $p$ op $r$ oor, en $r$ volg vanuit $p$; maar 'as $p$, dan $r$ ' is dikwels waar sonder dat $p$ op $r$ oorgedra word. Vir $p$ om oor te dra op $r$ is dit natuurlik wesenlik dat 'as $p$, dan $r^{\prime}$ 'n noodwendige waarheid is, maar Abelardus

29.Anders as talle ander Middeleeuse en ook sommige moderne logici, tref Abelardus ' $n$ duidelike onderskeid tussen ' $n$ predikaat en 'n stelling. ' $n$ Subjek en 'n predikaat mag saamgevoeg word sonder dat enige stelling gemaak word. 'God het die mens mag saamgevoeg word sonder dat enige stelling gemaak word. 'God het die mens die mens liefhet, gaan die mens hemel toe' sonder dat die stelling gemaak word (Abelardus 1971:160). Die logiese konsekwensie hiervan is dialekties-teologies natuurlik geweldig gevolgryk: 'n mens kan logies oor die subjek God en 'n predikaat praat, sonder dat enige stelling in die formeel-logiese sin van die woord gemaak word. wil daarmee verder gaan: 'As Sokrates ' $n$ klip is, dan is hy ' $n$ esel' is ' $n$ noodwendige waarheid - dit is onmoontlik vir Sokrates om 'n klip te wees en juis so onmoontlik dat hy ' $n$ klip sou moes wees sonder om ook 'n esel te wees (Abelardus 1971:293). Abelardus dring dus nie net daarop aan dat 'as $p$, dan $r^{\prime}$ 'n noodwendige waarheid moet wees nie, maar ook dat die noodwendigheid daarvan aan die inhoud van beide die antesedent en gevolg ontleen moet word: 'Daar moet 'n noodwendigheid van oordrag wees: naamlik, dat wat bedoel word met die gevolg gedetermineer word deur ' $n$ verstaan van die antesedent' (Abelardus 1971:253). Maar die 'noodwendigheid van oordrag' vereis nie die bestaan van die dinge waaroor die antesedent en gevolg dit het nie: 'As $x$ 'n roos is, dan is $x$ 'n blom' bly noodwendig waar 'ook al is daar geen rose meer in die wêreld nie' (Abelardus 1919:366). Dit is die dictum wat die oordrag dra, en die dictum is nie gedagtes of dinge in die wêreld soos rose nie.

Vyfdens vestig Abelardus se bydrae in sy onderskeid tussen twee verskillende wyses waarop oor potensialiteit of moontlikheid gepraat sou kon word..$^{30}$ 'n Proposisie soos 'Dit is moontlik vir die koning om nie koning te wees nie' kan so verstaan word: indien ons daaruit verstaan dat dit moontlik waar is dat die koning nie die koning is nie, is die proposisie duidelik vals (de sensu). Of ons sou daaruit kon verstaan dat die koning onttroon kan word, en dan is die proposisie inderdaad moontlik waar (de re). Die skolastici sou later telkens terugkeer na die teologiese gevolgrykheid van hierdie onderskeid.

Hierdie vyf fasette, hoe kursories dit ookal hier hanteer is, ondervang grotendeels Abelardus se bydrae tot die konstellasie taalbegrip-logika in die post-Carolingiese en voor-skolastiese periode van die eerste helfte van die 12de eeu. In die tweede helfte van die 12de eeu is die volledige Organon of logiese korpus vanuit Aristoteles se oeuvre na eeue se sistematisering vanuit die logica vetus en die Arabiese inwerking, met inbegrip van die wesenlike skarnierfunksie van Abelardus, beskikbaar gestel. Die Organon, gesupplementeer deur die Isagoge, die Boethiaanse weergawe van die logica vetus en die Abelardies-dialektiese taalbegrip-logika, tesame met 'n 12de-eeuse anonieme werk, Liber de Sex Principiis, sou vir die volgende eeue die kern van die logiese kurrikulum aan die jong Europese universiteite vorm - nou die logica novus - hoewel Abelardus se werk konstant gesubordineer is aan die Organon en eers in die latere Middeleeue weer skerper selfstandig sou begin funksioneer.

In die eerste helfte van die 13de eeu het daar egter ook twee universiteitshandleidings ten aansien van die konstellasie taalbegrip-logika verskyn, waarvan veral die tweede se invloed verreken moet word. Die eerste was die Introductiones in Logicam van die beroemde Oxfordiaan Willem van Sherwood. Die tweede, minder bekend, was 'n reeks tekste, gebundel as die Tractatus, later gesirkuleer as Summulae

30.Volgens Kenny (2004:127) is Abelardus se perspektief ontleen aan Aristoteles se Sophistici Elenchi (165b26); volgens Beukes (2011:7ev) rakende die Megariese oorsprong van die verhouding tussen aktualiteit en potensialiteit by Abelardus. 
Logicales, geskryf deur 'n Parysenaar, Petrus Hispanus, een van die mees ondergepubliseerde meewerkers tot die opkomende skolastiek en die bestendiging van die logica novus.

\section{Petrus Hispanus: Significatio, suppositio}

Biografies is daar weinig oor Petrus Hispanus beskikbaar en die gegewens wat wel beskikbaar is, is dikwels in dispuut. Hoewel hy in Anglo-Saksiese kringe as 'Peter of Spain' benoem is, funksioneer Spanje as 'n nasie-staat eers vanaf die laat-15de eeu en sou die genoemde 'Spanje' in die 13de eeu dus die hele Iberiese Peninsula moes veronderstel. Hoe 'n monnik van daardie uithoek af in Parys onder doseerskap van Willem van Sherwood sou land, is 'n ope vraag. Indien hy dan wel die Pedro Juliao (circa 1215-1277) was, wat later pous Johannes XXI sou word, is die biografiese inligting vanuit Vatikaansbronne natuurlik geredelik beskikbaar. ${ }^{31}$ Moontlik, selfs waarskynlik, was hy egter juis nie hierdie mees uitstaande student van Willem van Sherwood wat in Parys sou doseer en later pous sou word nie, maar 'n minder bekende, hoewel gerespekteerde Dominikaan, Castillianus, of ' $n$ ander, selfs minder bekende 'Swarttoga' Dominikaan, Petrus Ferrandi Hispanus (oorlede circa 1255 - die outeur is op grond van dateringskwessies en vanuit juis die margesnavorsing meer oortuig van laasgenoemde). Klaarheid hieroor in die navorsing is egter al vir eeue uitstaande. Wat nie in dispuut behoort te wees nie, en nogtans deur onderpublikasie gefrustreer word, ${ }^{32}$ is Hispanus se bydrae tot die konstellasie taalbegrip-logika in die 13de eeu.

Hispanus (1971:42ev) werk vanuit die Summulae Logicales mee tot die bestendiging van die logica novus deur, soos sy onmiddellike tydgenote, te fokus op sofismes (so genoem na Aristoteles se Sophistici Elenchi), vakterminologies genoem insolubilia - bedrieglike, selfs raaiselagtige sinskonstruksies wat fyn geanaliseer moet word ten einde nie tot absurde konklusies te lei nie. Byvoorbeeld, die stelling 'Ek lieg nou' is vals indien dit waar is en waar indien dit vals is. Die studie van insolubilia bestryk 'n groot deel van die konstellasie taalbegrip-logika in die 13de eeu. By hierdie studie van insolubilia word termlogika gevoeg as die eerste kenmerke van die logica novus. Termlogika sou nie net fokus op woorde of terme nie, maar ook die mentale teenhangers van terme. Terme word herken aan die woorde wat hulle tot uitdrukking bring en daarom is termlogika in die 13de eeu wesenlik die studie van die betekenisse van individuele woorde. Uit hierdie termlogika word mettergaande 'n uitgebreide begrippeskat gebore. Die mees algemene woord vir 'betekenis' was significatio, maar nie elke woord wat niebetekenisloos is, het significatio nie.

31.Vir " $n$ onlangse uiteensetting van die identiteitsverwarring rondom Petrus Hispanus en die verdediging van die tese dat Petrus Hispanus en pous Johannes XXI inderdaad dieselfde persoon was, kyk Degen en Bapst (2006:ix); kyk ook Haren (1992:148). Daar is egter sedert reeds die 15de eeu ' $n$ polemisering van hierdie
identiteitskoppeling en dit word steeds in die navorsing as kontroversieel en spekulatief beskou. Die identiteitsverwarring as sodanig dui op ' $n$ marginale figuur in die filosofiegeskiedenis.

32.Vergelyk in die sekondêre literatuur die karigheid van besprekings in die andersin punteneurige en omvangryke werk van Gilson (1955); asook in Coplesto (1972:235-236); Kenny (2005:129-1132) en Luscombe (2004:77-78).
Hispanus (1971:3) kategoriseer woorde in twee hoofklasse, naamlik die wat selfstandig oor significatio beskik (soos selfstandige naamwoorde) en die wat nie-selfstandig oor significatio beskik deur 'n konjunktiewe aangewesenheid op woorde met significatio. Die eerste, selfstandige hoofklas woorde noem Hispanus (1971:4) 'kategorematiese terme' en laasgenoemde hoofklas 'sinkategorematiese terme'. Sinkategorematiese termesluitin konjunktiewe, voorsetsels en voornaamwoorde, asook woorde soos 'slegs' in byvoorbeeld 'Slegs Paulus was die 13e apostel'. Kategorematiese terme voorsien sinne van inhoud en sinkategorematiese terme voorsien sinne funksioneel van struktuur en vorm. Aanvanklik sou gestel kon word dat die significatio van 'n woord iets soos 'n saaklike woordeboekbetekenis of leksikale betekenis sou kon wees: indien ons die betekenis van 'n woord leksikaal uit 'n woordeboek leer, eien ons onsself 'n konsep toe wat veelvoudig toegepas sou kon word (Hispanus 1971:4). Maar kategorematiese terme sou uiteindelik ook oor altyd-surplus semantiese eienskappe kon beskik, buite-om die leksikale significatio, afhangende van die wyse waarop die woorde in veelvoudige kontekste toegepas word. In die vier sinne, "n Kat krap aan die boom', "n Kat het vier pote', 'Neem jou kat veearts toe' en 'Jou kat het pas weer op die woonkamermat opgegooi', het die woord 'kat' dieselfde leksikale significatio in al vier die sinne, wat dus korrespondeer met 'n enkele woordeboekinskrywing, maar met uiteenlopende semantiese eienskappe wat verskil van $\sin$ tot $\sin$. Hierdie surplus semantiese eienskappe word deur Hispanus (1971:79ev) suppositio genoem. Die onderskeid tussen significatio en suppositio is wesenlik dieselfde as die latere moderne onderskeid, by Hume byvoorbeeld, tussen betekenis en verwysing. Hispanus (1971:81) noem die mees basiese suppositio 'natuurlike suppositio', waarmee die kapasiteit van enige term wat significatio het om vir enige saak waarop die term van toepassing gemaak kan word, as't ware 'in te staan', wat ook die letterlike betekenis van die Latynse woord suppositio is. Die wyse waarop hierdie kapasiteit in verskillende kontekste aangewend en uitgeoefen word, gee aanleiding tot verskillende vorme van suppositio.

Naas 'natuurlike suppositio' onderskei Hispanus (1971:81) verder ook 'n 'eenvoudige suppositio' van 'n 'persoonlike suppositio', naamlik dat die afwesigheid van 'n bepaalde of onbepaalde lidwoord ' $\mathrm{n}$ eenvoudige suppositio konstitueer: 'Mense is sterflik' verskil in die eenvoud van die bepaaldheid van die persoonlike suppositio "n Mens klop aan die deur', wat in die Afrikaanse taal ook dadelik weer eenvoudige suppositio sou moes word in "n Mens maak nie so nie'. Maar dan, in 'n filtrerende maneuver wat in die 14de eeu, onder meer vanuit Willem van Ockham se beroemde 'skeermesbeginsel' (kyk Beukes 2012:3), kenmerkend van die latere skolastiek sou word, onderskei Hispanus persoonlike suppositio in diskrete, gedetermineerde, distributiewe en verwarrende suppositio..$^{33}$ Hispanus (1971:88ev) onderskei dan drie verskillende wyses waarop ' $n$ woord subjekvervanging in ' $n$ sin moontlik kan maak, wat korrespondeer met diskrete, gedetermineerde en

33. Hierdie (soort) oefening in die termlogika het enersyds die doel om die logiese samehang in taalbegrip te verduidelik, maar andersyds om juis die potensieel verwarrende effek van taalbegrip te illustreer. 
distributiewe suppositio. In die sin 'Die hond het pas gedrink' is die woord 'hond' 'n diskrete suppositio: die predikaat is gebonde aan 'n pertinent enkele een van items waarvoor die term 'hond' gebruik kan word. Hierdie soort suppositio is gebonde aan eiename, aanwysende voornaamwoorde en beskrywings. By gedetermineerde suppositio, soos "n Hond krap aan die deur', heg die predikaat aan een spesifieke saak waarop die term 'hond' betrekking het, maar spesifiseer dit nie verder nie. By distributiewe suppositio, soos "n Hond het vier pote', heg die predikaat aan alles waarop die term 'hond' betrekking het. Gedetermineerde suppositio kan van distributiewe suppositio onderskei word deur byvoorbeeld te vra, 'watter hond?'. Indien die vraag betekenisvol beantwoord kan word, het ons te doen met gedetermineerde suppositio. Maar daarby stel Hispanus (1971:82) dat 'n woord nie alleen persoonlike suppositio kan voorbehou wanneer dit in die subjekplek geplaas word nie, maar ook wanneer dit as 'n predikaat funksioneer: dit is wat 'verwarrende suppositio' beteken. In 'Steffi is ' $n$ wolfhond' (of "n wolfhond is ' $n$ hond') is die suppositio van die term 'hond' verwarrend, in die sin dat dit, net soos met distributiewe suppositio, nie betekenisvol is om te vra 'watter hond?' nie. Elkeen van hierdie gelysde suppositio, 'eenvoudige', 'natuurlike' en daaronder die verskillende vorme van 'persoonlike suppositio', is formele suppositio, teenoor gematerialiseerde suppositio. Die onderliggende idee aan hierdie onderskeid is dat die klank van 'n woord die woord materialiseer, terwyl betekenis in die vorm van die woord gevind moet word.

Suppositio is weldra deur die latere Middeleeuse logici eerbiedig as die mees wesenlike semantiese eienskap van terme (vgl. Kenny 2005:131). Maar daarby is gevoeg appellatio, wat verband hou met die groter skopus van terme, en ook sinne. 'n Sin soos 'dinosourusse het lang sterte' roep die vraag na die appèllerende funksie van die betrokke stelling op. Is dit' $n$ betekenisvolle stelling, nou dat daar geen dinosourusse meer is nie? Indien uitgegaan word van die premisse dat die waarheid of valsheid van 'n sin gekonstitueer word op grond van die huidige statusinhoud van die aarde of selfs die heelal, kan die sin nie waar wees nie en kan die logiese probleem nie ondervang word deur die sin bloot in die verlede tyd te herskryf nie. Indien die sin as waar aanvaar wil word, sou dit logieserwys nie anders kon nie as om die waarheidswaarde daarvan te determineer op grond van die statusinhoud van die heelal in die verlede, teenswoordige en toekomstige tyd. Sonder hierdie toegewing aan die appèllerende funksie van stellings sou dit op geen stadium moontlik kon wees om enige iets betekenisvol oor enige antikwariese saak te kon stel nie. ${ }^{34}$ Hispanus se leermeester, Willem van Sherwood, het nie kans gesien om aan die implikasies hiervan toe te gee nie, wat tot ' $n$ bittere (hoewel betreklik tiperend van die intensiteit van Middeleeuse intellektuele konflikte) monnikeskeiding tussen Sherwood en Hispanus aanleiding gegee het.

Sherwood se uitgangspunt was dat die gangbare appèllerende funksie van terme is om slegs teenswoordig-bestaande objekte

34.Dit geld uiteraard vir dinosourusse, maar reeds Hispanus (1971:82) herken die wesenlike teologiese uitkomste wat logieserwys hiermee gebied word. Dit is na die wesenlke teologiese uitkomste wat logieserwys hiermee gebied word. Dit is na die appellerende funksie van die relevante stellinge moontlik om teologies-filosofieskultuurhistories oor God te praat en dit waarheidsvol te kan doen, ook in di afwesigheid van die onmiddellike semantiese bronne van die bepaalde stelling. te representeer en dat die term slegs as suppositio vir ' $\mathrm{n}$ niebestaande objek sou kon funksioneer indien 'n bykomende prosedure, ampliatio, wat wesenlik die nie-bestaande kwaliteit van die objek spekulatief verantwoord, bygevoeg word (vgl. Hispanus 1971:196). Hispanus daarenteen, bly die syns insiens wesenlike van appellatio handhaaf, naamlik dat die gangbare appèllerende funksie van terme is om as suppositio vir alle historiese, teenswoordige en toekomstige objekte te funksioneer. Indien die oogmerk inderdaad is om die term slegs vir die teenswoordige tyd of 'n teen(s)woordige objek te laat funksioneer, sou dit met 'n bykomende prosedure, wat dan weer restrictio genoem word, geaksentueer en verantwoord moes word (Hispanus 1971:199-208). Ampliatio en restrictio bring die logikus dan juis in gerig met twee teenoorstaandes in terme van die funksie van suppositio en beide Sherwood en Hispanus het mettertyd komplekse stelsels uitgewerk aan die hand van sowel die kontekstuele indikasies as implikasies van enersyds ampliatio of andersyds restrictio.

Hispanus se wesenlike bydrae tot die konstellasie taalbegriplogika was dus sy genuanseerde analise van termlogika aan die hand van suppositio. Die logiese konsekwensie van Hispanus se termlogika was om sy analise mettertyd in 'n groter sintaktiese en semantiese konteks te bed, naamlik in proposisielogika. Die wending vanaf termlogika na proposielogika is binne die konstellasie taalbegrip-logika dan ook die eerste en duidelikste wending vanaf die vroeg-13de na die middel-13de eeu, met ' $n$ progressief selfbestendigende middel-skolastiek wat, na 'n heranalise van Aristoteliaanse proposisiekritiek, groterwordende klem sou plaas op proposisiekritiek as sodanig. Dit het veral gemanifesteer in die verruiming van die nou behoorlik gevestigde logica novus in die werk van die gevierde Aquinas.

\section{Thomas Aquinas: Compositio et divisio}

Thomas de Aquino (1225-1274), of gewoon 'Aquinas' soos hy na die plek van sy vader se hertogskap in die skolastiek benoem is, is sonder enige twyfel die beroemdste en mees volledig ontginde en gekommentarieerde skolastikus van die 13de en 14de eeu. Ons sou daarmee kon volstaan om sowel sy tekstuele nalatenskap as intellektuele erfenis as enorm te beskryf. Die gevolgrykheid van Aquinas se prestasies vestig in sy bydrae tot die ontwikkeling van die logica novus deur die implementering van grondliggende Aristoteliaanse filosofiese premisses binne die raamwerk van die 13de-eeuse Christelik-dogmatiese sisteem, waaruit 'n oorspronklike Middeleeus-filosofiese sisteem ontstaan het wat sowel die pouslike tempering van die Groot Veroordeling van 1277, die Roomse Inkwisisie en veral die pedantiek van die moderne periode oorleef het. Aquinas se werk leef aktueel voort tot vandag toe. ${ }^{35}$ Geen ernstige geskiedsfilosoof of dogmenhistorikus slaan Aquinas oor nie.

35. Vergelyk in die sekondêre literatuur, wat uiteraard onoorsigtelik is, in besonde die resente bloemlesing van Bosley en Tweedale (2004:269-271); en daarby die uitstaande seleksies en kommentaar in Copleston (1972:178-198); Kenny (2005:136-139); Luscombe (2004:99-108) en Marenbon (2007:6068-6307). 
Net soos wat terme vir Hispanus mentale konsepte per suppositio tot uitdrukking bring, is daar in die tweede helfte van die 13de eeu, Aquinas se produksieperiode, die oortuiging dat sinne, stellings en proposisies mentale oortuigings (waaronder geloof) tot uitdrukking bring. In duidelike en konsekwente tematiese en metodologiese navolging van Aristoteles, word daar in die skolastiek onderskei tussen enkelvoudige gedagtes (wat tot uitdrukking gebring word in enkelwoorde) en meervoudige gedagtes (wat tot uitdrukking gebring word in woordkombinasies, soos in sinne of proposisies). Daar is hiervanuit, in navolging van Aristoteles, twee onderskeibare operatiewe stelreëls vir die intellek, ${ }^{36}$ naamlik die verstaan van enkelvoudige gedagtes en die verstaan van die komposisie van meervoudige gedagtes, soos proposisies. 'n Proposisie, volgens die tipies Middeleeuse verstaan daarvan, diep afhanklik van die voorskolastiese Abelardus (1971:154), is enige kombinasie van woorde wat iets tot uitdrukking bring wat ó waar óf vals is (vgl. ook Kenny 2005:132). By Abelardus het ons reeds geleer dat ons nie net moet vra wat individuele woorde beteken nie, maar ook wat hele sinne, stellinge of proposisies beteken. By Abelardus het ons egter ook gesien, in teenstelling met Aristoteles, dat ' $n$ meervoudige gedagte wat bestaan uit 'n subjek en ' $n$ predikaat nie noodwendig 'n oortuiging of idee tot uitdrukking bring nie. Aquinas (1966:1.3:26) se standpunt is dat ' $n$ proposisie, welke oortuiging of idee dit tot uitdrukking bring of nie, waar of vals is, met ander woorde, die proposisie sal feitelik met die werklikheid korrespondeer of nie korrespondeer nie. Dieselfde geld vir die korresponderende gedagte, synde ' $n$ oortuiging wat tot uitdrukking gebring word, of bloot die oorweging van ' $\mathrm{n}$ moontlike oortuiging wat moontlik tot uitdrukking gebring kan word. Maar die spraakhandeling wat die idee tot uitdrukking bring, en die korresponderende mentale handeling van beoordeling, bind die spreker of denker tot die waarheid aldan nie van die proposisie (vgl. De Rijk 1962:342)

Die vraag wat reeds so skerp by Abelardus gefigureer het-wat be-teken proposisies? - tree dus weer hier op die voorgrond. Indien met 'be-teken' bedoel word 'tot uitdrukking bring', is die antwoord volgens Aquinas (1966:1.3:27) selfevident: gesproke en geskrewe proposisies bring gedagtes in die verstand tot uitdrukking. Maar indien met 'be-teken' bedoel word 'tot betekenis bring', is die saak minder duidelik: dit wil voorkom of proposisies in hierdie sin niks in die werklikheid tot betekenis kan bring nie, omdat ' $n$ proposisie dieselfde moet be-teken, of dit nou waar en of dit nou vals is - en indien die proposisie vals is, is daar niks in die werklikheid wat daarmee korrespondeer en as sodanig tot uitdrukking gebring kan word nie. Ook in hierdie opsig bly Abelardus die geheime informant van die 13de-eeuse proposisiekritiek: dit is die 'stand van sake' (rerum modus habendi se), wat in die proposisie opgeneem is, wat die stelling waar maak. Ons het gesien dat Abelardus dit ' $n$ dictum noem. Presies wat die metafisiese status van sodanige dictum is (in die 13de eeu ook soms 'n enuntiabile genoem), was tot en met Aquinas grootliks

36. Die begrip 'intellek' in die skolastiek verwys strykdeur na' $n$ verstandelike fakulteit wat as 'n substansievorm onafhanklik van materie bestaan. onuitgeklaar. Een standpunt (vgl. De Rijk 1962:357ev) was dat die enuntiabilia nie substansies en ook nie kwaliteite is nie, maar dat dit ' $n$ afsonderlike metafisiese klas konstitueer wat nie deur Aristoteles se categoriae ondervang word nie, as sodanig nie tasbare entiteite nie, maar wel begrypbaar deur die verstand.

Die bestaan van so ' $n$ buitengewone klas word progressief in die skolastiek geproblematiseer. Die ander standpunt, wat hierdie toenemende problematisering van eersgenoemde standpunt voorsien het, was dat 'n bykomende vraag gevra moes word, naamlik: Watter soort ding is dit wat waar of vals is? Sinne, stellings, gedagtes en ' $\mathrm{n}$ dictum kan almal waar wees. Maar watter een hiervan is die dominante draer van waarheidswaarde? Hierdie vraag word besonder akuut wanneer die skolastici herhaaldelik vra na die verhouding tussen waarheid en tyd (De Rijk 1962:359). Sommige skolastici was van mening dat alles wat in sinne in natuurlike spreektale by wyse van tydsaanduidings gestel kan word, ook in ' $\mathrm{n}$ logiese taal sonder tydsaanduidings gestel kan word, en dan in sinne met tydsonbepaalde werkwoorde maar met ' $n$ eksplisiete tydsaanduiding of ' $n$ eksplisiete kwantifisering van tyd. In die sin 'Dit sal sneeu' uitgespreek in tyd $t 1$, sou hiervolgens 'n proposisie tot uitdrukking gebring word wat die gevolg het dat dit sneeu (tydloos) op 'n tyd $t$ later as $t 1$. Die vraag is dan of so ' $n$ 'hertaling' of revocio van tydsbepaalde sinne na tydlose proposisies gedoen sou kon word sonder ' $n$ verlies aan inhoud. Die meerderheid skolastici was nie entoesiasties oor so 'n 'hertaling' nie. Beide sinne en enuntabilia is hanteer as intrinsiek tydsbepaald. Aristoteles word in hierdie konteks in die 13de eeu gereeld aangehaal met sy stelling 'Sokrates sit', wat waar is wanneer Sokrates sit en vals is wanneer Sokrates opstaan (die teologiese gevolgrykheid hiervan ten aansien van God se tydlose kennis van gebeure in die tyd, wanneer 'dit' gebeur, spreek vanself). Die naaste wat die meerderheid skolastici aan tydlose proposisies sou kom, is met 'n disjunksie van tydsbepaalde sinne. So sou dit disjunktief maar logieserwys waar wees dat die Joodse profete en Christelike heiliges terselfdertyd 'n enkele objek van geloof onderskryf, naamlik die disjunktiewe proposisie 'Christus sal gebore word of Christus is gebore' (vgl. Kenny 2005:134).

Aquinas staan vierkant in hierdie debat. Hoewel hy weinig selfstandige bydraes tot die formele logika as sodanig gemaak het, anders dus as Abelardus en Hispanus, was dit Aquinas se vindingryke implementering van logiese konsekwensies in die taalbegrip wat sy bydrae konstitueer. Dit geld veral vir Aquinas se verskeidenheid van klassifiserings van spraakhandelinge en korresponderende komplekse of niekomplekse denkhandelinge. Dit vertrek weer vanuit die wesenlike Aristoteliese onderskeid tussen enkelvoudige gedagtes (wat tot uitdrukking gebring word in enkelwoorde) en meervoudige gedagtes (wat tot uitdrukking gebring word in woordkombinasies, soos in sinne of proposisies), waarna supra verwys is. 'Aristoteles stel in De Anima dat daar twee soorte aktiwiteit van die intellek bestaan: die eerste bestaan in die vormering van eenvoudige essensies, soos wat 'n mens 
of wat ' $n$ dier is. In hierdie aktiwiteit, op sigself, is daar geen waarheid of valsheid te vinde nie, net soos in nie-komplekse spraakuitinge. Die tweede aktiwiteit bestaan in die samestelling en disseminasie van essensies, deur affirmering of negering: in hierdie aktiwiteit is daar wel waarheid en valsheid te vinde, net soos in die komplekse spraakuitinge wat dit tot uitdrukking bring' (Aquinas 1955:14.1). Die onderskeid tussen hierdie twee denkaktiwiteite skakel met die verskil in taalbegrip tussen die gebruik van enkelwoorde en die samestelling van volledige sinne. Dit word geaksentueer wanneer Aquinas (1955) argumenteer dat enige denkaktiwiteit beskou kan word as die produksie van 'n 'binnewoord' of 'binnesin':

Die "woord" van ons intellek is die terminus van ons intellektuele aktiwiteit. Dit is die gedagte self, wat 'n "intellektuele konsepsie" genoem kan word; wat of 'n konsepsie is wat deur 'n nie-komplekse uiting tot uitdrukking gebring kan word, soos wanneer die intellek die essensie van dinge vorm, óf wat 'n konsepsie is wat tot uitdrukking gebring kan word deur 'n komplekse uiting, soos wanneer die intellek saamstel en skei.

(Aquinas 1955:4.2c, [outeur se eie beklemtoning])

Hierdie opvatting van 'saamstel en skei' is self nie so eenvoudig nie. Die paradigmatiese voorbeeld van sodanige 'saamstel en skei' was in die middel-skolastiek bloot die artikulering van affirmatiewe en negatiewe oordele (vgl. De Rijk 1962:360). Maar daar is volgens Aquinas ook ander soorte komplekse denkhandelinge. Afgesien van die oordeel $p$ en die oordeel nie- $p$, is daar ook die vraag of- $p$, of die vraag na $i n / p / i n$ (dus, $p$ in relasies). 'n Proposisie soos 'Iran huisves kernwapens' provokeer'n oordeel, in die affirmatief of in die negatief, wat uitgespreek of weerhou kan word, wat waar of vals kan wees, wat tentatief of met sekerheid gestel kan word, op die basis van logiese en redelike argumentvoering of juis die gebrek daaraan, of op die basis van selfevidente bewysplase. Aquinas, aan die begin van die enorme Summa Theologiae van 61 volumes, (1964-:1a-2a) klassifiseer komplekse $^{37}$ denkhandelinge dan op grond van hierdie moontlikhede: die weerhouding van ' $\mathrm{n}$ oordeel is dubitatio (twyfel); tentatiewe oordele waar ruimte vir foutering gelaat word, is opinio (opinie); sekere oordele gegrond op selfevidente bewysplase is intellectus (verstaan); sekere oordele gegrond op logiese en redelike argumentvoering is scientia (kennis); en sekere oordele gegrond op juis die gebrek aan logiese en redelike argumentvoering is credere of fides (geloof). Al hierdie moontlikhede konstitueer compositio et divisio, moontlikhede van 'saamstel en skei'.

Wat nie-komplekse denkhandelinge betref, handel Aquinas tweeledig hiermee: enersyds het nie-komplekse denkhandelinge te make met die bemeestering van bloot 'n woord. Indien iemand die betekenis van die woord 'yster' ken, sal die persoon in staat wees om die begrip te konseptualiseer en te kontekstualiseer, met ander woorde, die woord in onderskeid met ander woorde in 'n verskeidenheid van uiteenlopende kontekste te gebruik. Maar nie-komplekse denkhandelinge kan ook uniek kompleks wees, in die sin

37.Die begrip 'kompleks' dui in die skolastiese logika op enige soort proposisie wat uit eenvoudiger elemente bestaan wat mettergaande ontwikkel in nie-komplekse en helaas in komplekse terme. dat dit andersyds fokus op die essensie, of nader aan die skolastiese begrip, quidditeit ${ }^{38}$, van 'n saak. 'n Chemikus wat die eienskappe van yster in verband kan bring met die atomiese getal en plek daarvan op die periodieke tabel, het 'n nie-komplekse verstaan van yster. Aquinas (1964-:1a2) is gesteld op hierdie onderskeid in terme van nie-komplekse denkhandelinge: ons kan verstaan wat die woord 'God' beteken, maar ons kan God se quidditeit nie verstaan nie.

Hoe egter, skakel komplekse en nie-komplekse denkhandelinge met korresponderende spraakhandelinge? Hierdie vraag staan in die sentrum van die middel-skolastiese interpretasie van die konstellasie taalbegrip-logika en lei 'n aangrypende argument in. Aquinas (1955:2.4) se mees basiese oortuiging in hierdie verband is dat enige oordeel gemaak kan word binne die struktuur van 'n sin. Aquinas wil egter nie daarmee beweer dat elke oordeel noodwendig in woorde omgeskakel moet word of binne sinstruktuur, hetsy publiek of privaat in die verbeelding, tot uitdrukking gebring moet word nie. Wat hy wel beweer, is dat hoewel elke gedagte in taal uitgedruk kan word, dit nie alle gedagtes is wat in taal uitgedruk word nie en is dit selde dat gedagtes selfrefleksief juis oor taal self handel. Kontra-Platonies stel Aquinas (1964-:1a84) hoewel gedagtes in die intellek inderdaad universeel en immaterieel is, bestaan geen sodanige gedagtes ooit buite 'n intellek nie. Aquinas gee die Platoniese premisse toe dat die Vorme dinge bepaal soos wat hulle is; dat daar byvoorbeeld die Vorm 'mensheid' is wat van Sokrates "n mens' maak. Wat Aquinas nie toegee nie, is dat sodanige Vorm selfstandig en los van materie kan bestaan. Daar is buite die intellek nie iets soos 'menslike natuur' nie. Daar is alleen maar die menslike natuur van individuele mense (of menslike individue) soos Petrus, Paulus en Johannes. Daar is geen menslike natuur wat nie die natuur van ' $n$ individuele mens (of menslike individu) is nie en daarom is daar geen Universele Mens nie, nie 'in die hemel of op die aarde nie' (Aquinas 1964-:1a79). Menslike natuur bestaan in die intellek as 'n abstraksie, geabstraheerd juis vanuit individualiserende kenmerke, in uniforme verhouding tot alle mense wat buite die intellek bestaan. Daar is geen Idee van die Mens nie, alleen maar mense se idees van mense. Die menslikheid van ' $\mathrm{n}$ individu is 'dinkbaar' (vanuit die Vorm 'mens') maar nie 'werklik dinkbaar' (omdat dit in materie moet bestaan) nie (Aquinas 1964-:1a81). Om dit 'werklik dinkbaar' te maak, roep die ingrepe van 'n buitengewone intellektuele krag, wat Aquinas (1964-:1a80) regstreeks na Aristoteles die 'agentintellek ${ }^{\prime 39}$ noem, op. Die volgende stap is dan om te vra na die implikasies van Aquinas se kontra-Platoniese weergawe van universeles vir die semantiek van name en predikate.

38.Quidditeit, ' $n$ begrip regstreeks ontleen aan Avicenna en strykdeur aanwesig in die skolastiek, vra na die in quid van 'n saak, 'wat dit is om dit te wees'. Die quidditeit van ' $n$ saak moet uitgespel word in ' $n$ standhoudende definisie van die saak, en is soms, ietwat verwarrend, as sinoniem vir 'essensie' gebruik. By Avicenna self is die quidditeit van enige iets anders as God uitsluitend ten opsigte van die bestaan van die saak: Die saak se bestaan en daarom quidditeit (en andersom) word dus regstreeks aan God ontleen. So ' $n$ teologiese begrip van quidditeit verskil uiteraard dramaties van wat op'n periodieke tabel weergegee kan word - en tog is dit nie'n ander logika wat die rigiditeit daarvan dra nie.

39. Dit word in die skolastiek soms ook 'aktiewe intellek' genoem. Volgens Aristoteles word mense in staat gestel om (oor) abstrakte vorme te dink op grond van 'n intellek of ' $n$ aspek van mense se eie intellek wat ewig aktief is en in die passiewe intellek die vorme grondves wat verstaan kan word. Die passiewe intellek is die intellek of deel van die intellek wat nie altyd aktief is nie en ontvanklik is vir die intellek of deel van die intellek wat nie altyd aktief is nie en ontvanklik is vir
geabstraheerde vorme van dinge op grond van die agent-intellek se ingrepe. 
Aquinas wys hierdie implikasies uit met 'n beroep op 'n fundamentele universaliserende oorweging in die logica vetus, wat ons deeglik by Boethius ontmoet het, naamlik species. Die species 'hond' byvoorbeeld, bestaan nie materieel in die werklikheid nie en die species 'hond' is nie materieel deel van enige hond nie, hoewel honde 'n species is. Indien species-wees deel sou wees van wat dit is om 'n hond te wees, sou die wolfhond Steffi 'n species wees of kon wees. Wanneer ons beweer dat honde ' $n$ species is, beweer ons nie werklik enige iets aangaande honde nie. Wat ons wel na Aquinas se mening doen, is om 'n tweede-orde stelling oor ons eie konsepte te mak: ons impliseer in die eerste plek dat die konsep 'hond' universeel is en van toepassing is op enige en alle honde. Tweedens impliseer ons dat 'hond' 'n saamgestelde konsep is wat ander konsepte as die konstituente daarvan het, byvoorbeeld, 'dier'. Genus en species word dus gedefinieer in terme van predikate en predikate word deur die intellek bedink, as't ware 'opgemaak', in die vormering van affirmatiewe en negatiewe proposisies.

Hierdie posisionering ten aansien van compositio et divisio bepaal uiteindelik Aquinas se posisie ten opsigte van analogiese taalgebruik. Aquinas (1964-:1a13) onderskei tussen twee soorte analogiese taalgebruik: die analogie van attributio of passio ${ }^{40}$ kan verduidelik word aan die hand van die konsepvoorbeeld 'gesond'. Streng gesproke kan slegs lewende dinge soos plante en diere gesond wees. Maar ons praat ook van 'n 'gesonde dieet'. Ons kan die konsep 'gesond' vir'n dieet gebruik omdat dit implisiet of per attribuut na die persoon, plant of dier verwys wie se dieet tersprake is. Die analogie van proportio aan die ander kant, kan verduidelik word met die konsepvoorbeeld 'goed'. Slegs morele en etiese subjekte kan 'goed' wees. Tog praat ons ook van 'n 'goeie perske' of 'n 'goeie kar'. Baie duidelik is die 'goed' van die perske en die 'goed' van die kar verskillende soort 'goed' en tog is beide implisiet of per proporsie ontleen aan die 'outentieke goed' in morele sin. Iets in die perske of kar roep iets van die morele 'goed' op, sonder dat die perske of kar self moreel is of word. Wanneer ons dan woorde gebruik om oor God en mense te praat, gebruik ons dieselfde woorde (byvoorbeeld liefde, of vryheid), maar hierdie 'dieselfde woorde' word nie dieselfde gebruik nie; eerder analogies dieselfde, hetsy per attribuut of per proporsie. Wanneer ons beide God en Sokrates 'wys' noem, gebruik ons dieselfde woord, sonder om dit as metafoor te wil gebruik. Ons gebruik dit spontaan analogies (Aquinas 1964-):

Hierdie gebruik van woorde vestig iewers tussen suiwer ekwivokaliteit en eenvoudige univokaliteit, ${ }^{41}$ omdat die woord nooit in dieselfde sin gebruik word nie, soos wat dit met univokaliteit die geval sou wees, maar ook nie heeltemal verskillend nie, soos wat die geval met ekwivokaliteit sou wees.

(Aquinas 1964-:1a13)

40.Die begrip passio in Middeleeuse filosofie verwys na ' $n$ karaktertrek wat tot ' $n$ sekere soort subjek behoort, maar nie genoem word in die definisie van daardie subjek nie. Dat die attribuut tot die subjek behoort, is ' $n$ logiese afleiding vanuit die definisie self.

41.'Univokaliteit' dui op die gebruik van ' $n$ bepaalde term in ' $n$ bepaalde sin wat daartoe lei dat die term in dieselfde sin op meer as een tipe saak van toepassing gemaak kan word, sonder verlies of wysiging aan inhoud. 'Ekwivokaliteit' daarteenoor, dui op die gebruik van ' $n$ bepaalde term in ' $n$ bepaalde sin wat wat daartoe lei dat die term nie in dieselfde sin op meer as een tipe saak van toepassing gemaak kan word sonder verlies of wysiging aan inhoud nie.
Ons het inderdaad ver gevorder vanaf die rudimentêre semiotiek van Augustinus na die analogiese ekwivokaliteit van Aquinas. Met hierdie analogiese posisionering van die verhouding tussen taalbegrip en logika dek Aquinas die tafel vir die latere skolastiek van die 14de en 15 de eeu om op die konstellasie taalbegrip-logika vanuit die logica vetus na die logica novus, voort te borduur. In die opvolgende artikel word daarom aandag gegee aan die standpunte van Johannes Duns Skotus en Willem van Ockham, maar dan ook, binne die stemming van hierdie rehabiliterende projek, aan die tradisioneel ondergepubliseerde perspektiewe van Johannes Wyclif en Petrus de Rivo.

\section{Erkenning}

Hierdie artikel word opgedra aan my hoogs gewaardeerde leermeester in sowel die teologie as die kerk, Prof. Dr. T.F.J. Dreyer. Vanuit net die hoogste respek is ek Professor Theuns Dreyer baie meer verskuldig as waarvan ek met ' $n$ konstellasie van woorde, sinne en 'n logiese struktuur blyke kan gee. Ek dank God vir u, Professor.

\section{Mededingende belange}

Die outeur verklaar dat hy geen finansiële of persoonlike verbintenis het met enige party wat hom nadelig kon beïnvloed in die skryf van hierdie artikel.

\section{Literatuurverwysings}

Abelardus, P., 1919, Logica: Logica Ingredientibus \& Logica Nostrorum Petitioni, Beitrage zur Geschichte der Philosophie des Mittelalters, vol. 15, Aschendorff, Münster.

Abelardus, P., 1971, Dialectica, ed. L.M. de Rijk, Van Gorcum, Assen.

Ackrill, J., 1963, Aristotle: Categoriae \& De Interpretatione, Clarendon Press, Oxford.

Aquinas, T., 1955, De Veritate, ed. R.M. Spiazzi, Marietti, Turin.

Aquinas, T., 1964-, Summa Theologiae, Blackfriars Edition, 61 vols., Eyre \& Spottiswoode, London.

Aquinas, T., 1966, In II Libros Perihermeneias Aristotelis Expositio, ed. R.M. Spiazzi, Marietti, Turin.

Aristoteles, 1995, 'Categoriae', in J. Barnes (ed.), The Complete Works of Aristotle, pp. 3-25, transl. J.L. Ackrill, Princeton University Press, Princeton.

Armstrong, A.H. (ed.), 1967, The Cambridge history of later Greek and early Medieval philosophy, Cambridge University Press, London.

Augustinus, 1978, 'De Magistro', in J.M. Colleran (ed., transl. \& comm.), Ancient Christian Writers: St Augustine - The Greatness of the Soul \& The Teacher, pp. 129-189, Newman (Paulist) Press, New Jersey.

Augustinus, 1985, De Dialectica, ed. D. Jackson, Reidel, Dordrecht.

Augustinus, 1992, Confessiones, J.J. O’Donnell (ed., transl. \& comm.), Clarendon Press, Oxford.

Beukes, J., 2005, 'Terreur, roes en ordes: Die monnik as blywende simbool van erns in die filosofie', HTS Teologiese Studies/Theological Studies 61, 1101-1129.

Beukes, J., 2011, 'God kan net doen wat God wel doen: Petrus Abelardus se Megariaanse argument in Theologia Scholarium, Opera Theologia III', HTS Teologiese Studies/Theological Studies 67(1), Art. \#124, 1-15.

Beukes, J., 2012 'Die konstellasie taalbegrip-logika in die Middeleeuse filosofie (2): Duns Skotus tot De Rivo', HTS Teologiese Studies/Theological Studies 68 (forthcoming).

Boethius, 1877, Commentarii in librum Aristoteles, Perihermeneias I-II, C. Meiser (ed.), Teubner, Leipzig.

Boethius, 1891, Opera Omnia, Patrologia Latina 64, ed. J-P. Migne, Apud Editorem, Harvard.

Boethius, 1934, De consolatione Philosophiae, ed. W. Weinberger, Corpus Scriptorum Ecclesiasticorum Latinorum 67, Kommission zur Herausgabe des Corpus der lateinischen Kirchenväter (CSEL), Österreichische Akademie der Wissenschaft, Wenen.

Boethius, 1978, De Topicis Differrentiis, transl. E. Stump, Cornell University Press, New York. 
Bosley, R.N. \& Tweedale, M. (eds.), 2004, Basic issues in medieval philosophy: Selected readings presenting the interactive discourses among the major figures, Broadview Press, Ontario.

Brower, J., \& Guilfoy, K. (eds.), 2004, The Cambridge companion to Abelard, Cambridge University Press, New York.

Burnyeat, M.F., 1987, 'Wittgenstein and St Augustine's De Magistro', Proceedings of the Aristotelian Society 61, 1-12.

Chadwick, H., 1981, Boethius: The Consolations of Music, Logic, Theology and Philosophy, Clarendon Press, Oxford.

Clanchy, M.T., 1999, Abelard: A Medieval life, Wiley-Blackwell, London.

Colish, M.L., 1968, The mirror of language: A study in the medieval theory of knowledge, Yale University Press, New Haven, CT.

Copleston, F.C., 1972, A History of Medieval Philosophy, Methuen, London.

Crosson, F.J., 1999, 'Structure and meaning in St Augustine's Confessions', in G.B. Matthews (ed.), The Augustinian Tradition, pp. 27-38, University of California Press, Berkeley, CA.

Dahmen, R., 1906, Darstellung der Abälardischen Ethik, Münster Verlag, Münster.

De Rijk, L., 1962, Logica Modernorum, Van Gorcum, Assen.

Degen, W. \& Bapst, W., 2006, 'Die alte Zuschreibung zu Papst Johannes XXI', in Petrus Hispanus: Logische Abhandlungen, Univ Munchen Verlag, Munich.

Dronke, P. (ed.), 1988, A history of twelfth-century Western philosophy, Cambridge University Press, Cambridge, UK.

Frakes, J.C., 1988, The Fate of Fortune in the Middle Ages: The Boethian tradition Studien und Texte zur Geistesgeschichte des Mittelalters, Leiden, Brill.

Gilson, E., 1955, History of Christian philosophy in the Middle Ages, Random House, New York.

Grabmann, H., 1909, Die Geschichte der scholastischen Metode, vol. I, Herder Freiburg.

Haren, M., 1992, Medieval thought: The Western intellectual tradition from antiquity to the thirteenth century, University of Toronto Press, Toronto.

Hispanus, P., 1971, Summulae Logicales, ed. L.M. de Rijk, Van Gorcum, Assen.

Hyman, A., 1973, Philosophy in the Middle Ages: The Christian, Islamic and Jewish traditions, Hackett, Indianapolis, IN.

Kenny, A., 2005, Medieval Philosophy, A New History of Western Philosophy, vol. II, Clarendon Press, Oxford

Kirwan, C., 1991, 'The nature of speech', in Augustine: The Arguments of the philosophers, pp. 28-47, Routledge, New York.

Klibansky, R., 1982, The continuity of the Platonic tradition during the Middle Ages, Kraus, New York.

Kretzmann, N., Kenny, A. \& Pinborg, J., 1982, The Cambridge history of later Medieval philosophy, Cambridge University Press, Cambridge, UK.

Kretzmann, N., 1998, 'Boethius and the truth about tommorow's sea battle', in N. Kretzmann (ed. \& transl.), Boethius: On Aristotle, De Interpretatione 9, pp. 24-52, Duckworth, London.
Leff, G., 1958, Medieval thought: St Augustine to Ockham, Penguin, Harmondsworth. Luscombe, D.E., 1969, The School of Peter Abelard: The influence of Abelard's thought in the early scholastic, Cambridge University Press, Cambridge.

Luscombe, D.E., 1992, 'The School of Peter Abelard revisited', Vivarium 30, 127-138. http://dx.doi.org/10.1163/156853492X00098

Luscombe, D.E., 2004, Medieval Thought, Opus-Oxford University Press, London.

Marenbon, J., 1988, Early Medieval philosophy (488-1150): An introduction, Routledge, New York.

Marenbon, J., 1999, The philosophy of Peter Abelard, Cambridge University Press, Cambridge.

Marenbon, J., 2007, Medieval Philosophy: An Historical and Philosophical Introduction Routledge, Taylor \& Francis e-Library, London.

McCabe, J., 1972 [1901], Peter Abelard, Burt Franklin Research and Source Works Series: Philosophy \& Religious History Monographs 110, Lenox Hill, New York.

Mews, C.J., 1986, 'On dating the works of Peter Abelard', Archives d'Histoire Doctrinale et Littéraire du Moyen Age 60, 73-134.

Mews, C.J. \& Jolivet, J., 1990, 'Peter Abelard and his influence', in G. Floistad (ed.), pp. 105-140, Contemporary Philosophy 6/1: Philosophy and Science in the Middle Ages, Kluwer, Amsterdam.

Mews, C.J., 2001, Abelard and his legacy, Aldershot, Ashgate.

Minio-Paluello, L., 1972, 'The genuine text of Boethius' translation of Aristotle's Categories', in Opuscula: The Latin Aristotle, pp. 1-12, Hakkert, Amsterdam.

Murray, A.V., 1967, Abelard and St Bernard: A study in twelfth-century 'modernism', Barnes \& Noble, New York.

Price, B.B., 1992, Medieval thought: An introduction, Blackwell, Oxford.

Russell, B., 1961, History of Western Philosophy, Allen \& Unwon, London.

Spade, P.V., 1995, Five texts on the medieval problem of universals, Hackett, Indianapolis, IN.

Stewart, H.J., Rand, E.K. \& Tester, S.J. (eds. \& transl.), 1973, Boethius: The Theological Tractates and The Consolation of Philosophy, Loeb Classical Library, Harvard University Press, Cambridge.

Sweeney, E.C., 2006, 'Abelard: A twelfth-century hermeneutics of suspicion', in Logic, theology, and poetry in Boethius, Abelard, and Alan of Lille: Words in the absence of things, pp. 63-126, Palgrave Macmillan, New York.

Tweedale, M., 1976, Abailard on universals, North-Holland, Amsterdam.

Wadell, H., 2008, Peter Abelard, Buck Press, Bubuashie.

Weinberg, J.R., 1964, A short history of Medieval philosophy, Princeton University Press, Princeton.

Weingart, R.E., 1970, The logic of divine love: The soteriology of Peter Abailard, Oxford University Press, Oxford.

Wilks, I., 2008, 'Peter Abelard and his contemporaries', in D. Gabbay \& J. Woods (eds.), Medieaval and Renaissance Logic, pp. 83-156, Elsevier, Amsterdam.

Wills, G., 1999, Saint Augustine: A Life, Penguin, London.

Wittgenstein, L., 1953, Philosophical Investigations, Blackwell, Oxford. 